NBER WORKING PAPER SERIES

\title{
THE PRICE EFFECTS OF A LARGE MERGER OF MANUFACTURERS: A CASE STUDY OF MAYTAG-WHIRLPOOL
}

\author{
Orley C. Ashenfelter \\ Daniel S. Hosken \\ Matthew C. Weinberg \\ Working Paper 17476 \\ http://www.nber.org/papers/w17476
}

\author{
NATIONAL BUREAU OF ECONOMIC RESEARCH \\ 1050 Massachusetts Avenue \\ Cambridge, MA 02138 \\ October 2011
}

The opinions expressed here are those of the authors and not necessarily those of the Federal Trade Commission, any of its Commissioners, or the National Bureau of Economic Research. We thank Princeton Univesity for financial assistance. We also thank Mike Mazzeo, Paul Pautler, Chuck Romeo, Carl Shapiro, and Mike Vita for comments.

NBER working papers are circulated for discussion and comment purposes. They have not been peerreviewed or been subject to the review by the NBER Board of Directors that accompanies official NBER publications.

(C) 2011 by Orley C. Ashenfelter, Daniel S. Hosken, and Matthew C. Weinberg. All rights reserved. Short sections of text, not to exceed two paragraphs, may be quoted without explicit permission provided that full credit, including $(\odot)$ notice, is given to the source. 
The Price Effects of a Large Merger of Manufacturers: A Case Study of Maytag-Whirlpool Orley C. Ashenfelter, Daniel S. Hosken, and Matthew C. Weinberg

NBER Working Paper No. 17476

October 2011

JEL No. K2,K21,L11,L4

\section{ABSTRACT}

Many experts speculate that U.S. antitrust policy towards horizontal mergers has been too lenient. We estimate the price effects of Whirlpool's acquisition of Maytag to provide new evidence on this debate. We compare price changes in appliance markets most affected by the merger to markets where concentration changed much less or not at all. We estimate price increases for dishwashers and relatively large price increases for clothes dryers, but no price effects for refrigerators or clothes washers. The combined firm's market share fell across all four affected categories and the number of distinct appliance products fell.

Orley C. Ashenfelter

Industrial Relations Section

Firestone Library

Princeton University

Princeton, NJ 08544

and NBER

c6789@princeton.edu

Daniel S. Hosken

Federal Trade Commission

600 Pennsylvania Avenue, NW

Washington, DC 20580

dhosken@ftc.gov

\author{
Matthew C. Weinberg \\ Dalton Hall \\ Bryn Mawr College \\ Bryn Mawr, PA 19010 \\ L ADDRESS HERE \\ mweinberg@brynmawr.edu
}




\title{
The Price Effects of a Large Merger of Manufacturers: A Case Study of Maytag-Whirlpool
}

\author{
Orley C. Ashenfelter, Daniel S. Hosken, and Matthew C. Weinberg*
}

\begin{abstract}
Many experts speculate that U.S. antitrust policy towards horizontal mergers has been too lenient. We estimate the price effects of Whirlpool's acquisition of Maytag to provide new evidence on this debate. We compare price changes in appliance markets most affected by the merger to markets where concentration changed much less or not at all. We estimate price increases for dishwashers and relatively large price increases for clothes dryers, but no price effects for refrigerators or clothes washers. The combined firm's market share fell across all four affected categories and the number of distinct appliance products fell.
\end{abstract}

Each year thousands of mergers are proposed to the U.S. Federal Trade Commission and U.S. Department of Justice. After filing, the merging firms must wait while the antitrust authority attempts to identify and block mergers that would increase consumer prices. The challenge of identifying those mergers that would increase prices while not interfering with those that would not is enormous. Enforcement decisions must be made quickly and often with imperfect information on consumer demand, the ease of entry, and the possibility of merger induced efficiencies. Unsurprisingly, whether antitrust enforcement has been too lenient or too strict is the subject of much debate (Crandall and Winston (2003), Baker (2003)). A straightforward way to inform this debate is to evaluate whether approved mergers actually increased price. Without evidence of this sort, it is impossible to know whether antitrust policy is achieving the objective of protecting consumer surplus.

\footnotetext{
${ }^{*}$ The opinions expressed here are those of the authors and not necessarily those of the Federal Trade Commission or any of its Commissioners. We thank Mike Mazzeo, Paul Pautler, Chuck Romeo, Carl Shapiro, and Mike Vita for comments. Ashenfelter: c6789@princeton.edu, Hosken: dhosken@ftc.gov, Weinberg: mweinberg@brynmawr.edu
} 
This paper presents exactly that kind of evidence by estimating the price effects of a large and controversial merger-Whirlpool's acquisition of Maytag. This merger combined two of the largest appliance manufacturers in the United States, and is particularly interesting for our purposes because it was likely nearly blocked. ${ }^{1}$ The Whirlpool/Maytag case arguably presents an opportunity to evaluate whether a change in antitrust policy, allowing a merger that otherwise would have been challenged, resulted in a price increase.

Using scanner data covering a period before and after Whirlpool's purchase of Maytag, we estimate how markets for different types of appliances were impacted by the acquisition. Before the merger Whirlpool and Maytag were both large manufacturers of clothes washers, clothes dryers, dishwashers, and refrigerators. In contrast, both firms had essentially no presence in the market for freezers and Maytag was a relatively less important producer of cooktops, ovens, and ranges. Comparing the prices of dryers, washers, refrigerators, and dishwashers to appliance markets that experienced no or small changes in concentration before and after the merger offers a simple test of whether the merger increased prices. We find that the prices for dishwashers and clothes dryers increased relative to each comparison appliance category, we find small price changes for refrigerators, and essentially no change in prices of washing machines.

Comparisons within appliance categories between products produced by Maytag or Whirlpool and rival appliance manufacturers provide an alternative test of whether the merger raised prices. Consistent with models of oligopoly commonly used to study mergers (Deneckere and Davidson (1985)), we find evidence that dryers and dishwashers owned by the merging parties and introduced after the merger occurred experienced an increase in price relative to rivals' dryers and dishwashers introduced after the merger occurred.

We also estimate the effects of the merger on market share and a simple measure of

\footnotetext{
${ }^{1}$ Baker and Shapiro state, "the perception that the Justice Department has adopted a very lax merger enforcement policy was unquestionably fueled by the March, 2006 decision of Assistant Attorney General Barnett not to take any enforcement action when Whirlpool sought to obtain Maytag," and that they are "confident that the Whirlpool/Maytag deal would have been challenged by Assistant Attorney General Klein 10 years ago."
} 
product variety. Consistent with our estimated price effects, we find that the merging parties' combined market share fell in the product categories experiencing the largest price increases. However, similar decreases in relative sales were experienced in other appliance categories for which prices did not increase. We also find that the number of distinct products, as measured by Stock Keeping Units (SKUs), offered to consumers by Whirlpool/Maytag fell after the merger, both in absolute terms and relative to rival appliance manufacturers.

This paper complements a small number of papers that directly estimate the effects of mergers in consumer product markets. ${ }^{2}$ The studies in this literature are typically case studies. This approach makes it feasible to focus on industry specific institutions that are often necessary to account for when estimating merger effects. ${ }^{3}$

The evidence on whether mergers increase prices is mixed and limited primarily to industries with a history of regulation, e.g. banking, airlines, petroleum, and hospital mergers, which might not be generalizable to other sectors of the economy. ${ }^{4}$ As pointed out by Carlton (2009), determining if mergers of competitors lead to increased prices is potentially complicated by a selection issue-the antitrust agencies attempt to identify and block mergers that would increase prices paid by consumers. Selection implies that the average price change resulting from a random sample of approved mergers will be a lower bound on the average price effect of a merger in a world with no merger enforcement. This lower bound, however, is not an informative measure of whether potentially problematic mergers allowed by the government have increased prices, because the over-

\footnotetext{
${ }^{2}$ See Whinston (2006) for a survey and Weinberg (2008) or Hunter, Leonard and Olley (2008) for a more recent survey focusing on the empirical literature.

${ }^{3}$ The literature on collusion (see Asker (2010) and Genesove and Mullin (2001)) also frequently uses the case study approach.

${ }^{4}$ Examples include Borenstein (1990) and Kim and Singal (1993) studies of airline mergers, Focarelli and Panetta (2003), Sapienza (2002), and Prager and Hannan (1998) studies of banking mergers, and Hastings (2004) Taylor and Hosken (2007), and Simpson and Taylor (2008) studies of gasoline mergers. Chandra and Collard-Wexler (2009) estimate the price effects of Canadian newspaper mergers. Winston, Dennis and Maheshri (2011) study two large railroad mergers using a different approach. This paper estimates demand and supply and assumes a model of competition to study the short and long-run effects mergers.
} 
whelming majority of proposed mergers raise no competitive concerns. ${ }^{5}$ A more useful measure of whether antitrust enforcement is at the right level is the average effect of mergers that were nearly blocked. A negative mean price effect of the marginal merger would imply enforcement is too strict; that is the government is discouraging acquisitions that would result in lower final good prices. Similarly a positive price effect would imply that merger enforcement has been too lenient. This paper attempts to account for this selection issue by focusing on the Maytag-Whirlpool case precisely because it's viewed as a merger that was nearly challenged during a time period in which relatively few mergers were challenged. ${ }^{6}$

We begin the paper by providing background information on the merger. We next describe the data and the construction of our sample of appliances. We then report the detailed results of our study and explore the robustness of our findings.

\section{Merger Background}

Whirlpool's acquisition of Maytag was much more controversial than the typical antitrust case. In mid-2005 a group of private investors agreed to purchase Maytag for $\$ 1.13$ billion. Before this transaction was consummated, the Haier Group (a Chinese owned appliance manufacturer), offered $\$ 1.3$ billion dollars for Maytag. While Haier was the leading appliance manufacturer in China, it had relatively little presence in the U.S. According to press reports, Haier's goal was to move the manufacturing of Maytag's products to its much lower cost Chinese factories while maintaining Maytag's extensive U.S. dealer and service network. ${ }^{7}$ Haier's proposed acquisition was controversial both because of general concerns

\footnotetext{
${ }^{5}$ Ashenfelter and Hosken (2010) report that from 1991-2004, $97 \%$ of mergers proposed to the regulators went consummated without modification.

${ }^{6}$ For example, Baker and Shapiro cite a January 2007 Wall Street Journal article reporting that "The federal government has nearly stepped out of the antitrust business ...the message is clear for deals with antitrust issues: It's now or never."

7 "China's Haier withdraws Maytag bid on pricing, integration concerns", Forbes, July 20, 2005.
} 
about the purchase of well-known U.S. brands by Chinese firms and the potential loss of a large number of relatively high paid manufacturing jobs. On July 17th the largest U.S. appliance manufacturer, Whirlpool, offered to purchase Maytag for $\$ 1.4$ billion. On July 20th Haier Group withdrew its offer to purchase Maytag. Ultimately, Whirlpool was able to purchase Maytag for $\$ 1.79$ billion after a long investigation by the U.S. Department of Justice's antitrust division (DOJ) on March 30, 2006. Because of the large increase in concentration in several appliance markets, visibility of the merging parties, and the alleged incongruity with the DOJ's relatively long history in enforcement action towards mergers in traditional manufacturing industries, the merger and DOJ's decision received significant attention both amongst antitrust experts and the popular press, much of it negative. $^{8}$

The merger reduced the number of major appliance manufacturers (Whirlpool, Maytag, GE, and Electrolux) in the United States from four to three. Both Maytag and Whirlpool had sales in seven of the eight major home appliance categories: dishwashers, clothes dryers, refrigerators, clothes washers, cooktops, ovens, and ranges. ${ }^{9}$ Within each appliance category there is substantial product differentiation. ${ }^{10}$ There are two leading sources of differentiation. The first comes from measurable product characteristics. Second, products are also differentiated by brand marketing. The major appliance manufacturers typically sell luxury variations of their appliances under a different brand name. Further, a number of smaller niche firms sell very high end appliances in each major category. Miele and Bosch, for example, sell very expensive, quiet, and highly efficient dishwashers and LG sells relatively expensive and efficient front loading washing machines.

\footnotetext{
${ }^{8}$ See "Arguments for Whirlpool-Maytag Just Don't Wash", Washington Post, 2/22/2006 and Baker and Shapiro (2008).

${ }^{9}$ Prior to the merger only Electrolux was a significant participant in the eight category, freezers. According to Moss (2006), Maytag and Whirlpool began selling freezers in 2005. However, in our data neither firm had more than a one percent revenue share of freezer sales before the merger occurred.

${ }^{10}$ For example, the ratio of the price in the 75 th percentile of the price distribution to the 25 th percentile ranges from 1.7 for dishwashers to 2.8 for ovens.
} 
According to public documents, much of Justice's investigation focused on clothes washers and dryers. ${ }^{11}$ While the merger increased concentration most dramatically in the washer and dryer markets, it also substantially affected concentration in the markets for dishwashers and refrigerators. Table 1 contains pre-merger revenue shares calculated using our data. Whirlpool was the largest manufacturer in each of these appliance categories, and Maytag was the second largest producer of washers and dryers. Table 2 presents premerger market shares for cooktops, freezers, ovens, and ranges. ${ }^{12}$ Maytag had relatively little market share in these categories, and while the merger did increase concentration in cooktops, ovens, and ranges, it did so to a much lesser extent than for dryers, washers, dishwashers, and refrigerators.

One of the largest appliance brands, Kenmore, is owned and sold exclusively by the retailer Sears. Sears contracts with appliance manufacturers like Whirlpool to produce all of its Kenmore appliances. Our data does not contain information on Kenmore. While this poses no problem in directly estimating the price effects of the merger on the products for which we do have data, we are unable to determine if Kenmore's prices changed differentially from its competitors.

\section{Data and Sample Construction}

Our data from the NPD Group covers each of the major appliance categories. We obtained the most disaggregated data NPD would provide: national monthly retail unit sales and revenues for each appliance measured at the level of a specific appliance model, defined

\footnotetext{
${ }^{11}$ The Department of Justice's statement is available at http : //www.usdoj.gov/atr/public/press releases/2006/215326.htm

${ }^{12}$ Most of the appliance products we study are essentially self-explanatory. There may be some ambiguity among the three appliance categories used to cook food. A cooktop is an appliance that contains burners (powered by electricity or natural gas) to cook food. An oven is an appliance that holds an enclosed space for cooking food, such as baking a cake. A range is an appliance that contains both a cooktop and an oven. A range is the most frequently purchased cooking appliance in a U.S. kitchen. Ovens and cooktops are sold separately and typically professionally installed in a kitchen.
} 
as a stock keeping unit (SKU). The data spans the time period from January 2005 to September 2008. NPD collects its data from a nationally representative sample of national and regional major appliance retailers. Representatives of NPD told us that the codes used to identify appliances (SKUs) are unique to a product and common across retailers; that is, different retailers selling an identical product will sell a product with a common SKU. ${ }^{13}$ Our data set also includes a rich set of descriptive information for each appliance including brand name and product characteristics. ${ }^{14}$ Product characteristics explain a large fraction of the variation in appliance prices, typically 85 to 95 percent.

There are two institutional features of appliance markets that are important for our study. First, products in six of the eight appliance categories we study (clothes washers and dryers, dishwashers, freezers, refrigerators, and ranges) have, on average, relatively short shelf lives lasting roughly one calendar year. The price and volume sold of these products declines as the date in which a product exits the market approaches. This can be seen by examining the relationship between an appliance product's price and unit sales and its age. We estimate this relationship separately for each appliance category in equations (1) and (2) below, conditional on observing each product's birth:

$$
\begin{aligned}
& \log p_{i t}=\alpha_{i}+\sum_{k=2}^{25} \theta_{k} \text { Age }_{i t}^{k}+\sum_{l=2}^{43} \delta_{l} \text { TimePeriod }_{i t}^{l}+e_{i t} \\
& \log q_{i t}=\psi_{i}+\sum_{k=3}^{25} \lambda_{k} \text { Age } e_{i t}^{k}+\sum_{l=3}^{43} \gamma_{l} \text { TimePeriod }_{i t}^{l}+u_{i t}
\end{aligned}
$$

where $\alpha_{i}$ and $\psi_{i}$ are product specific fixed effects, $A g e_{i t}^{k}$ are age indicators, and TimePeriod ${ }_{i t}^{l}$ are separate indicators for each month in our regression sample. Figures 1 and 2 plot the coefficients corresponding to the Age indicators in equations 1 and 2 respectively. ${ }^{15}$ Ovens

\footnotetext{
${ }^{13}$ To protect a retailer's confidentiality, NPD does not release disaggregated data which would allow a researcher to identify a specific retailer. Within our data less than $1.4 \%$ of sales are not associated with a specific product.

${ }^{14}$ See the appendix for a list of the characteristics that describe each appliance type in our data.

${ }^{15}$ The age coefficients in Figure 1 are measured relative to prices in the product's first month with positive sales. Because our data is measured at the monthly frequency we cannot determine how many
} 
and cooktops appear to be relatively long lived and do not experience systematic declines in pricing or sales with age in their first 25 months on the market. Unit sales of ovens and cooktops, for example, at twenty months of age appear to be very similar to sales in their fourth month. Similarly, prices appear to be relatively constant over time. The other appliance categories appear to have much lower prices and unit sales as a product ages. Prices fall significantly after a product has been on the market for more than one year, typically more than $10 \%$, and monthly unit sales fall by about $50 \%$ relative to a product's sales after it has been on the market for a few months. In the remainder of this study we limit attention to the pricing of models within their first full year of existence due to the rapidly declining price and volume profile at the end of a product's lifetime. Further, because the shape of the age-sales and age-pricing relationship varies across appliance categories, all analysis will include separate controls for age for each appliance category.

Second, there is significant heterogeneity in the level of sales of different appliance products in our data. In our data more than 14,000 appliances (defined by a unique SKU) are introduced during our sample period. Most of these appliances, however, have a very small number of unit sales. Very small differences in product type generate a unique SKU, e.g., a product's color. It could be that some minor variants of an appliance have small sales (more than $93 \%$ of dryers are white). Alternatively some small volume SKUs may not be real products, but instead the result of a coding error, e.g., an erroneously entered SKU number. To minimize this type of measurement error we focus attention on models that have a relatively high volume of sales. For the smaller appliance categories, freezers, ovens, and cooktops, we restrict attention to appliances that have at least 100 unit sales within the product's first 13 months on the market. ${ }^{16}$ Refrigerators, dishwashers, weeks within a month the item has been on sale in its first month; that is, for most of the items in our data the first month's sales correspond to a partial month. For this reason in measuring how an item's unit sales change with age we drop the month in which the product was introduced and measure the age coefficients relative to month 2's volume.

${ }^{16}$ Total unit sales of all cooktops, freezers and ovens in their first 13 months on the market are 65,738, 445,886 , and 61,085 respectively in our data. These models account for $66 \%$ of cooktop sales, $99 \%$ of freezer sales, and $66 \%$ of oven sales. 
clothes dryers, washing machines, and ranges are higher volume products, so we restrict our sample to models having 1000 unit sales in the first 13 months on the market. ${ }^{17}$

\section{Price Effects of the Merger}

The major issue faced by any study attempting to estimating the effect of a merger on consumer prices is to develop a reasonable estimate of the counterfactual change in prices had the merger not occurred. Simply comparing the merging firms' average prices after the merger to their average prices beforehand assumes this counterfactual change is zero, and this simple time difference will be biased if something unrelated but concurrent in timing to the merger also affected prices. For example, an increase in the price of steel coincident with the merger would bias a simple time difference estimator of the merger's effect on prices upwards. In order to avoid this assumption, we follow the literature and estimate the price effects by comparing the change in pricing to that of a comparison group. For this approach to be valid, it must be the case that the change in price of the comparison group is the counterfactual change in price that would have occurred for the brands owned by the merging firms had the merger not occurred.

Major appliances are highly durable goods that are frequently purchased in conjunction with new home building or home remodeling. A natural control product for our study would be a major appliance category unaffected by the merger. Prior to the merger both Maytag and Whirlpool sold products in seven of the eight major appliance categories for which we have data. The degree of pre-merger competition between Maytag and Whirlpool, however, likely varied across product categories. Maytag and Whirlpool were major competitors in four appliance categories: dishwashers, refrigerators, clothes

\footnotetext{
${ }^{17}$ Total unit sales of all refrigerator, dishwasher, clothes dryer, range, and clothes dryer sales in their 13 months on the market are 3.9 million, 1.9 million, 3.4 million, 2.4 million, and 4 million in our data. These models account for $90 \%$ of refrigerator sales, $92 \%$ of dishwasher sales, $98 \%$ of clothes dryer sales, $90 \%$ of range sales, and $99 \%$ of clothes washer sales.
} 
washers, and clothes dryers (see Table 1 for revenue shares by manufacturer for these appliance markets). In each of these categories the markets appear to be highly concentrated with Whirlpool typically having about $40 \%$ of sales and Maytag having a share between $9 \%$ and $16 \%$ in these categories.

In contrast, the degree of competition between Maytag and Whirlpool, as suggested by revenue shares, appears less substantial in the cooktop, freezer, oven, and range product categories. In our data neither Whirlpool nor Maytag had a presence in the freezer market prior to the merger's consummation. While the range market has a similar level of pre-merger concentration as the markets shown in Table 1, Maytag's market share was relatively small at $5.1 \%$. Maytag's pre-merger share is somewhat larger in the cooktop and oven markets at $9.2 \%$ and $6.2 \%$, respectively. However, the level of pre-merger concentration is significantly lower than in dishwashers, refrigerators, clothes washers and dryers. For this reason, and the fact that these categories were not mentioned in public accounts of DOJ's investigation, we use cooktops, freezers, ovens, and ranges as comparison groups. Further, in Baker and Shapiro's (2008) account of the merger, only clothes dryers and washers were explicitly mentioned as areas of concern. To further reduce the possibility that these comparison products experienced a price increase related to the merger, we restrict the comparison group to brands not produced by Maytag or Whirlpool. While the Bertrand model of Deneckere and Davidson (1985) predicts that rivals will increase prices after the merger for most demand systems, they will do so by a smaller extent than the merging firms.

\subsection{Graphical Evidence}

To determine if the merger increased appliance prices, we start by plotting average (log) prices of Maytag and Whirlpool appliances in the markets where concentration changed the most: dishwashers, clothes dryers and washers, and refrigerators. For comparison, we 
also plot average prices of two appliance categories for which the merger arguably should have had little if any effect: freezers and ranges that were not produced by Maytag or Whirlpool.

Figure 3 contains the results with freezers as a comparison, and Figure 4 contains the same plots but with ranges that were not produced by Maytag or Whirlpool for comparison. The vertical lines indicate the date the merger was consummated, April of $2006 .^{18}$ Recall that in order to avoid selection issues associated with left censoring, we restricted our sample to products first introduced during the time period spanned by our sample. This restriction causes our sample size to be very small in the first few months of our sample. As a result our estimates of the monthly average log price during the first few months of our sample are noisy. Therefore, when constructing the figures we exclude the first four months of data and take the starting point to be June of 2005.

The figures plotting the raw data are somewhat noisy. There is some suggestive evidence that the prices of dishwashers, dryers, and clothes washers increased relative to both freezers and ranges over the sample period, but the exact timing of the relative price increase varies somewhat by category. Dishwasher prices increased soon after the merger but clothes washer and dryer prices increased several months afterwards. More importantly, two issues make these graphs difficult to interpret as revealing the effects of the merger. First, as seen in Figure 1, product prices decrease as they become older and the composition of dishwashers, dryers, and clothes washers that are late in their life may vary relative to the comparison appliances. If the composition of freezers becomes older relative to dryers, this could generate the price profiles in Figures 3 and 4. Second, if the composition of higher end and more expensive dryers sold increased over the sample period, the graphs may simply reflect that.

In order to address these issues, we next plot how average prices conditional on observable characteristics and age vary over the sample period for each type of appliance.

\footnotetext{
${ }^{18}$ The exact date was March 30, 2006.
} 
This was done by first fitting the following equation to the data with OLS separately for each of the eight appliance categories:

$$
\log \left(p_{i t}\right)=\sum_{j} \delta_{j} x_{i j}+\sum_{k=3}^{13} \theta_{k} \text { Age } e_{i t}+\sum_{l=2}^{43} \gamma_{l} \text { TimePeriod }_{t}^{l}+\epsilon_{i t}
$$

where $x_{i j}$ is characteristic $j$ of product $i$, the $A g e_{i t}$ are age dummies, and the TimePeriod ${ }_{t}^{l}$ are month dummies. The omitted month dummy corresponds to the first month in the data. We then plot the $\{\hat{\gamma}\}_{t=5}^{43}$ against the corresponding time period. ${ }^{19}$

Figure 5 plots the adjusted prices of dishwashers, dryers, clothes washers and refrigerators against freezers. Figure 6] contains the same plots, but with ranges instead of freezers. The average prices after conditioning on product characteristics and age are less volatile than the raw data. While overall, dishwasher, dryer, and clothes washer prices increased relative to both freezers and ranges, the figures may mask important differences in pricing between products introduced before and after the merger date. We explore this possibility in the next section.

\subsection{Regression Estimates}

We carry out inference by estimating how the prices of washers, dryers, dishwashers, and refrigerators changed before and after the merger relative to four comparison groups: freezers, ranges, cooktops and ovens. A natural starting point fits the following equation to the data using OLS separately for each "treatment" / "comparison" pair:

$$
\begin{aligned}
& \log \left(p_{i t}\right)=\beta_{1} * \text { Maytag }_{i} * \text { PostMerger }_{t}+\beta_{2} * \text { Whirlpool }_{i} * \text { PostMerger }_{t} \\
& +\sum_{k=3}^{13} \theta_{k}^{T} A g e_{i t}^{T}+\sum_{k=3}^{13} \theta_{k}^{C} A g e_{i t}^{C}++\sum_{l=2}^{43} \delta_{l} \text { TimePeriod }_{i t}^{l}+\alpha_{i}+\epsilon_{i t}
\end{aligned}
$$

\footnotetext{
${ }^{19}$ Again, we start the plots in June of 2005 due to the small number of SKU's in the initial months in our sample.
} 
where $p_{i t}$ is the average price of SKU $i$ in month $t .^{20} \alpha_{i}$ is an SKU-specific fixed effect,

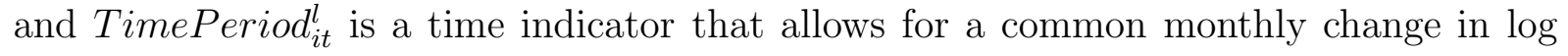
prices in month $l . A g e_{i t}^{C}$ and $A g e_{i t}^{T}$ are a series of age indicators corresponding to the appliance's age in months for the comparison and treatment category, respectively. The key parameters are $\beta_{1}$ and $\beta_{2}$, which measure the change in the log price of Maytag and Whirlpool products relative to the change in log price of each comparison appliance category. $^{21}$

The presence of the SKU specific fixed effects $\alpha_{i}$ in 4 implies that the price effects are identified from products that existed both before and after the merger occurred. It is impossible to identify the effect using products that did not exist both before and after the merger, as for these products the Maytag $_{i} *$ PostMerger $_{t}$ and Whirlpool $_{i} *$ PostMerger $_{t}$ are perfectly collinear with the SKU fixed effects. This shortcoming is potentially important: most products in the markets affected by the merger have short lifetimes, roughly a year. The price effect of the merger could be systematically different for products existing prior to the merger relative to those introduced after the merger. For example, the merged firm might maintain its prices on products introduced prior to the merger (on average, six months from the end of their life cycle), and increase the price of products introduced following the merger. To explore this possibility, we replace the SKU fixed effects with a linear combination of observable characteristics such as brand dummies, a stainless steel indicator, and product size. ${ }^{22}$ We estimate the following

\footnotetext{
${ }^{20}$ Most merger retrospectives estimate some variation of this equation. See Weinberg (2008) for a review and description of the various comparison markets and products that have been used.

${ }^{21}$ Allowing separate time dummies for each month is more flexible than controlling only for common pre and post-merger difference and allowing for SKU specific fixed effects is more flexible than allowing for only a time invariant difference in the conditional mean between maytag/whirlpool and other brands. Of course, one cannot control for both a post merger dummy and monthly time effects nor both SKU fixed effects and a Maytag or Whirlpool dummy.

${ }^{22} \mathrm{~A}$ list of product specific characteristics (all specifications include brand dummies) used for each type of appliance is located in the data appendix. Measuring a product's quality using observed product characteristics is a common approach used in the matching of new and discontinued products in price measurement. The U.S. Bureau of Labor Statistics, for example, estimates hedonic regressions to estimate the value of new product characteristics to control for changes in product quality.
} 
equation using OLS:

$$
\begin{aligned}
& \log \left(p_{i t}\right)=\sum_{j} \delta_{j}^{T} * x_{i j}^{T}+\sum_{h} \delta_{h}^{C} * x_{i h}^{C}+\sum_{l=2}^{43} \theta_{l}^{C} \text { TimePeriod }_{i t}^{l} \\
& +\beta_{1} * \text { Maytag }_{i} * \text { PostMerger }_{t}+\beta_{2} * \text { Whirlpool }_{i} * \text { PostMerger }_{t} \\
& +\sum_{k=3}^{13} \theta_{k}^{T} \text { Age }_{i t}^{T}+\sum_{k=3}^{13} \theta_{k}^{C} \text { Age }_{i t}^{C}+\epsilon_{i t}
\end{aligned}
$$

The $x_{i j}^{T}$ include characteristics and brand dummies for Whirlpool/Maytag appliances and $x_{i h}^{C}$ include characteristics and brand dummies of the comparison appliances. ${ }^{23}$ Standard errors are clustered by SKU.

While specification 5 has the advantage that it can be used to estimate separate price effects for products introduced after the merger was consummated, a potential drawback is that if there are unobservable characteristics that systematically changed after the merger occurred, the OLS estimator of 5 will be biased. To explore the efficacy of using characteristics to control for product heterogeneity we estimate both equations 4 and 5 on the sample of SKU's introduced within one year of the merger's consummation date, April 1, 2006. If unobservable product characteristics result in bias of the OLS estimator of 5, we would expect the estimates of $\beta_{1}$ and $\beta_{2}$ to be different when estimated in specification 4 than in specification 5 .

The estimated price effects are shown in Appendix Tables 1-4, where each table corresponds to a different comparison group. Appendix Table 1, for example, presents the estimated price effects for the four most affected appliance markets using cooktops as the comparison group. The first two columns show that the estimated price effects for dishwashers using either product fixed effects (column 1) or product characteristics (column 2) are virtually identical, about $4 \%$ for Whirlpool and 3\% for Maytag. The estimated

\footnotetext{
${ }^{23}$ Note $x_{i j}^{T}$ are non-zero only if the SKU is a Maytag or Whilpool appliance and $x_{i h}^{C}$ are non-zero only if the SKU is a comparison appliance.
} 
price effects for the other appliance markets in Appendix Table 1 are remarkably similar (typically within $0.1 \%$ ) when using either fixed effects or product characteristics to control for an SKU's quality. This pattern holds not only when cooktops are used as a comparison category, but also when freezers, ovens, or ranges are used for comparison (see Appendix Tables 2-4, respectively). This finding suggests that unobserved time-invariant product characteristics within an SKU are not correlated with the post-merger dummies, conditional on observable characteristics. Because of the potential importance of pricing differences for products introduced after the merger, and because the specifications with fixed effects and product characteristic controls yield virtually identical merger effects, we use measured product characteristics to control for product quality in the remainder of this paper.

We next use a slight variation of specification 5 that allows the Maytag and Whirlpool interactions with the post-merger dummy to vary by whether the product was introduced before or after the merger date. This allows us to examine whether the merged manufacturer changed pricing differently for products introduced after the merger date. We estimate the price effects on an expanded sample including all products that were born within our sample period. Adding products that did not exist both before and after the merger increases the sample size by between 35 and 57 percent, depending on the appliance category. ${ }^{24}$

Tables 3-6 present the estimated price effects for dryers, dishwashers, refrigerators, and clothes washers relative to each the four comparison appliance categories. In summary, we find systematic price increases for products introduced after the merger occurred in two categories: dryers and dishwashers. Despite experiencing a large change in market structure similar to the dryer market, we do not observe evidence of a price increase for clothes washers. The results for refrigerators are more mixed. There is some evidence

\footnotetext{
${ }^{24}$ We also estimated all of the models using the level of prices as the dependent variable instead of the $\log$ of price, and find qualitatively similar results. These results are available upon request.
} 
of a small price increase, 2-4\%, for Whirlpool refrigerators, however, this price effect is imprecisely estimated and not as robust as the findings for clothes dryers or dishwashers. The results for products introduced before the merger occurred are less robust to the choice of comparison group. When measured relative to cooktops or freezers, appliance prices appear to have increased while the price effects are much smaller (and sometimes negative) when measured relative to ranges and ovens. We cannot reach a conclusion as to how the merger affected pricing for these products.

The detailed results for dryers are presented in Table 3. The bottom two rows show that across each of the four comparison appliance categories, the prices of newly introduced Whirlpool and Maytag dryers increased. The magnitude of the price increase was large for Whirlpool dryers, between 13 and 17 percent depending on the comparison group, and the results are statistically significant at conventional levels. While the point estimates suggest that prices of new Maytag dryers increased as well, the magnitude was less than 5 percent and we are unable to reject the null of no price increase at the .10 level. The evidence on the impact of the merger on the prices of dryers that were introduced before the merger is less robust. Relative to freezers and cooktops, pre-existing Maytag dryer prices increased, but no effect is found relative to the other two comparison categories. The estimates for Whirlpool dryers introduced before the merger indicate small price decreases, if anything.

The results for dishwashers are presented in Table 4. Prices of Maytag dishwashers introduced after the merger increased by between 5 and 7 percent and are statistically significant at the .05 level, while Whirlpool dishwasher pricing remained essentially unchanged. There is some evidence that prices of dishwashers introduced before the merger increased as well, though the magnitudes are fairly sensitive to choice of comparison appliance category.

Tables 5 and 6 present the results for refrigerators and clothes washers. Whirlpool re- 
frigerator prices introduced after the merger increased slightly by $2-4 \%$, and we can reject the null of no price change at the .05 level for all specifications except when comparing to freezers. We find no significant price changes for Maytag refrigerators, and none for refrigerators introduced by the parties before the merger was consummated. Interestingly, we find no evidence that the merger resulted in price changes for Maytag or Whirlpool clothes washers.

As an additional test, we compare the change in Maytag and Whirlpool appliance prices relative to rivals' prices within each appliance category. To calculate these price effects we estimate the following variant of equation 5 separately for each appliance category:

$$
\begin{aligned}
& \log \left(p_{i t}\right)=\sum_{j} \delta_{j} * x_{i j}+\sum_{k=3}^{13} \theta_{k} * \text { Age }_{i t}+\sum_{l=2}^{43} \delta_{l} * \text { TimePeriod }_{i t} \\
& +\beta_{1} * \text { Maytag }_{i} * \text { PostMerger }_{t} * \text { PreMergerProduct }_{i} \\
& +\beta_{2} * \text { Whirlpool }_{i} * \text { PostMerger }_{t} * \text { PreMerger Product }_{i} \\
& +\beta_{3} * \text { Maytag }_{i} * \text { PostMerger }_{t} * \text { PostMergerProduct }_{i} \\
& +\beta_{2} * \text { Whirlpool }_{i} * \text { PostMerger }_{t} * \text { PostMerger Product }_{i}+\epsilon_{i t}
\end{aligned}
$$

where $x_{i j}$ are appliance characteristics and the other variables are as defined above. To the extent that the merger increased prices, rivals may have increased prices in the postmerger equilibrium as well. This would be true in the differentiated product Bertrand model commonly used to simulate mergers and studied in Deneckere and Davidson (1985). In this model, the extent to which rivals increase price depends on how quickly the absolute value of demand elasticities increase as prices increase (Crooke, Froeb, Tschantz and Werden (2003)). However, for a large class of demand systems Deneckere and Davidson show that the merging firms will increase price by more than rivals. Therefore, if this model describes pricing well, and if the merging firm's products are important substitutes 
for other appliances in the same category, then the estimated price effects from equation (6) will be biased down but of correct sign.

The results appear in Table 7. The estimated price effects are generally consistent with the findings from the other comparison groups. Starting with column 1 we see that dishwashers introduced prior to the merger by Maytag and Whirlpool increased slightly more than other manufacturers' dishwashers. This is within the range seen in Table 3 for the other control groups. Similarly, we see that Maytag dishwashers had a relatively large price increase of $8 \%$ relative to other manufacturers' dishwashers. We also observe a large price increase for Whirlpool dryers introduced following the merger, roughly $7 \%$ relative to other manufacturers' dryers. Finally, consistent with the other comparison groups, the relative price of Maytag's and Whirlpool's refrigerators do not appear to have changed much relative to the prices of other firms' refrigerators. Maytag and Whirlpool's clothes washer prices, however, appear to have decreased relative to prices of rival clothes washers.

\subsection{Market Shares and Product Variety}

The focus of our study is to determine if the acquisition of Maytag by Whirlpool increased consumer prices. While the results vary somewhat with the choice of comparison appliance category, overall we interpret our findings as indicating an increase in the price of Maytag dishwashers and Whirlpool clothes dryers. We next examine whether the combined Whirlpool/Maytag's output falls in response to the price increases we observed. We conduct this test by examining how the market share (either revenue or unit sales) of the merged firm changed following the merger in each appliance market.

We estimate the change in the merging parties' average monthly market share with a simple regression of Whirlpool/Maytag's monthly market share on a merger dummy. The results for volume shares are in column 1 of Table 8 and the results for revenue shares are in 
column 2. Volume and revenue shares fell significantly in each product category following the merger, and not just those experiencing a relative price increase. Refrigerators' and clothes washers' average revenue shares, for example, fell by an estimated 8.6 and 7.3 share points following the merger.

Why should Whirlpool/Maytag's share of these categories have fallen so much following the merger? One possibility is that the merged firm changed their product offerings. We next explore whether Whirlpool/Maytag changed the number of items it sells. To do this, we first identify distinct items (SKUs) that were sold in each time period. As noted earlier, many SKUs in our data set have very few sales. For this reason, we limit our attention to relatively high volume SKUs sold by appliance manufacturers. Specifically, we calculate the number of SKUs with at least 100 unit sales sold by Whirlpool/Maytag and all other appliance manufacturers for each month in our sample, and examine how the number of items available for sale each month changed following the merger. ${ }^{25} \mathrm{We}$ first plot the number of SKUs offered each month by Whirlpool/Maytag and all other manufacturers in Figure 7. The plots show a systematic drop in the relative number of Whirlpool/Maytag SKUs offered for sale following the merger in each of the four most affected appliance categories. The changes are most pronounced for clothes washers and dryers where the combined Whirlpool accounted for the majority of items offered premerger and a minority of items post-merger. Regressions of the monthly count of distinct Whirlpool/Maytag SKUs on a post-merger dummy are reported in column 3 of Table 8 . The average monthly number of different products sold fell across appliance categories in absolute terms, by about 10 units per month for Dryers and Washers and by about 12 SKUs for refrigerators. The absolute reduction in SKUs was quite small for dishwashers: roughly $1 \mathrm{SKU}$.

To further explore the effect of the merger on our simple measure of product variety,

\footnotetext{
${ }^{25}$ SKUs with at least 100 monthly sales account for the overwhelming majority of unit sales in the most affected markets: $98 \%$ of clothes washers, $97 \%$ of clothes dryers, $93 \%$ of dishwashers and $91 \%$ of refrigerators.
} 
we also estimate the relative change in the number of products sold by Whirlpool/Maytag to account for the possibility that appliance manufacturers may have changed the number of product offerings in response to either changes in demand or cost, e.g., an increased or decreased demand for variety. We do this by estimating the following equation:

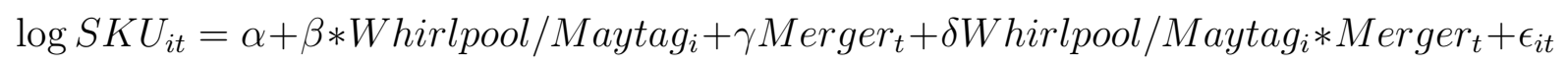

where the dependent variable is the log of the number of high volume SKUs sold in month t

(by any appliance manufacturer), Whirlpool/Maytag $g_{i}$ is an indicator for Whirlpool/Maytag, and Merger $_{t}$ is an indicator for the post-merger period. We interpret the coefficient on the interaction term, $\delta$, as the relative proportional change in the number of appliances offered by Whirlpool/Maytag following the merger. The results are in column 4 of Table 8 , In relative terms, the reduction in variety is substantial for all four product categories. This implies rival manufacturers were increasing the number of products offered in these appliance markets while Whirlpool/Maytag was reducing its product offerings. Variety was reduced, at least to the extent that SKU counts are a reasonable measure of variety.

\section{Conclusions}

Merger analysis is inherently prospective: the government must quickly make predictions about how large discrete changes in market structure will affect markets. Forecasting how changes in market structure will change consumer prices, costs, and incentives to innovate is extraordinarily difficult. In the roughly 30 years since the passage of the Hart-ScottRodino Act (which essentially started federal review of prospective mergers), the antitrust agencies and the federal courts have developed methodologies, expertise, and expectations about the types of information that will be probative in determining if mergers are likely to harm consumers. Only by estimating the price effects of consummated mergers, however, 
can we learn if the decision making process used by the courts and antitrust agencies is successful in identifying and blocking mergers that raise consumer prices.

We have estimated the price effects of Whirlpool's acquisition of Maytag because the decision to not challenge this merger appears to be a break with previous government decision making. The merger greatly increased concentration in several appliance markets that were already concentrated. Both the popular press and academic economists stated that the merger would have been challenged in the previous administration. Therefore, this merger provides a relatively unique opportunity to examine if more lenient treatment of mergers results in competitive harm.

This merger is also interesting because in contrast to most allowed mergers (where the government states nothing about its reason for allowing the merger), the Department of Justice provided a somewhat detailed justification for its decision. The Justice Department stated that its investigation focused on laundry products (washers and dryers) and that within this sector three factors led them to conclude that any attempt to raise prices would likely be unsuccessful. First, the two largest domestic manufacturers (Electrolux and GE) had substantial excess capacity and could expand output. Moreover, recent successful foreign entrants (LG and Samsung) could import more products into the U.S. in response to an anticompetitive price increase. Second, sales of the majority of appliances are made by a small number of large retailers (Sears, Best Buy, Lowes, and Home Depot) who "have alternatives available to help them resist an attempt by the merged entity to raise price." Third, "the parties (Maytag/Whirlpool) substantiated large cost savings and other efficiencies that should benefit consumers." 26 We have estimated the price effects of the merger for the four major appliance categories where the change in market concentration was highest: washers and dryers, which were the focus of the government's investigation, and refrigerators and dishwashers. Relative to four comparison appliance categories, we find price increases for some, but not all, types. Prices of

\footnotetext{
${ }^{26}$ Department of Justice Closing statement, dated March 29, 2006.
} 
Whirlpool clothes dryers and Maytag dishwashers introduced after the merger increased by roughly $14 \%$ and $7 \%$, respectively. We do not see systematic evidence of any price change (increase or decrease) for Maytag or Whirlpool refrigerator or clothes washers.

Given Maytag and Whirlpool's very similar pre-merger market share in the clothes washer and dryer markets, we find it somewhat surprising to observe a price increase only for dryers. One difference between the washer and dryer markets cited by the DOJ is that the U.S. washer market is experiencing a change in technology. Consumers are switching from traditional top loading washing machines, where Maytag and Whirlpool were most successful, to more expensive but more efficient front loading machines. In this segment, Whirlpool and Maytag were less successful and faced strong competition from imports (such as Samsung and LG). In contrast, the dryer market is not undergoing a similar change. The competitive factors the DOJ cited, particularly recent successful entry by Samsung and LG, may have played an important role in maintaining washer pricing. In total, however, the factors cited by the DOJ do not appear to have been sufficient to maintain pre-merger price levels for either clothes dryers or dishwashers.

Obviously, mergers change much more than a firm's pricing incentives. Firms likely change their marketing strategies, product mix, and may be able to lower their costs following mergers and acquisitions. Empirical work shows that mergers can affect a firms optimal product selection (see, e.g., Sweeting (2010) and Berry and Waldfogel (2001)), and that reductions in variety induced by merger can significantly reduce consumer welfare (Draganska, Mazzeo and Seim (2010)). We observe a large reduction in the number of distinct items (stock-keeping units or SKUs) offered to consumers following the acquisition, and this reduction is largest in the clothes washer and dryer markets that were the focus of the government's investigation. If the number of distinct SKUs are a meaningful measure of product variety, this finding suggests that the merger may have resulted in a large, and potentially important, reduction in variety. 


\section{References}

Ashenfelter, Orley C. and Daniel S. Hosken, "The Effect of Mergers on Consumer Prices: Evidence from Five Mergers on the Enforcement Margin," Journal of Law and Economics, 2010, 53, 417-466.

Asker, John, "A Study of the Internal Organisation of a Bidding Cartel," American Economic Review, 2010, 100 (3), 724-62.

Baker, Jonathan, "The Case for Antitrust Enforcement," Journal of Economic Perspectives, Fall 2003, $17(4), 27-50$.

Baker, Jonathan B. and Carl Shapiro, "Reinvigorating Horizontal Merger Enforcement," in R. Pitofsky, ed., Where the Chicago School Overshot the Mark: The Effect of Conservative Economic Analysis on Antitrust, Oxford University Press, 2008.

Berry, Steven T. and Joel Waldfogel, "Do Mergers Increase Product Variety? Evidence From Radio Broadcasting," The Quarterly Journal of Economics, August 2001, 116 (3), 1009-1025.

Borenstein, Severin, "Airline Mergers, Airport Dominance, and Market Power," American Economic Review, May 1990, 80 (2), 400-404.

Carlton, Dennis, "The Need to Measure the Effect of Merger Policy and How to Do It," Competition Policy International, 2009.

Chandra, Ambarish and Allan Collard-Wexler, "Mergers in Two-Sided Markets: An Application to the Canadian Newspaper Industry," Journal of Economics and Mangement Strategy, Winter 2009, 18 (4), 1045-1070. 
Crandall, Robert W. and Clifford Winston, "Does Antitrust Policy Improve Consumer Welfare? Assessing the Evidence," Journal of Economic Perspectives, Fall 2003, $17(4), 3-26$.

Crooke, Philip, Luke Froeb, Steven Tschantz, and Gregory J. Werden, "The Effects of Assumed Demand Form on Simulated Post-Merger Equilibria," Review of Industrial Organization, Nov 2003, 15 (3), 205-217.

Deneckere, Raymond and Carl Davidson, "Incentives to Form Coalitions with Bertrand Competition," The RAND Journal of Economics, 1985, 16, 473-86.

Draganska, Michaela, Michael Mazzeo, and Katja Seim, "Addressing Endogenous Product Choice in an Empirical Analysis of Merger Effects," Working Paper, Northwestern University 2010.

Focarelli, Dario and Fabio Panetta, "Are Mergers Beneficial to Consumers? Evidence from the Market for Bank Deposits," American Economic Review, September 2003, $93(4), 1152-72$.

Genesove, David and Wallace P. Mullin, "Rules, Communication, and Collusion: Narrative Evidence from the Sugar Institute Case," American Economic Review, 2001, $91(3), 379-98$.

Hastings, Justine S., "Vertical Relationships and Competition in Retail Gasoline Markets: Empirical Evidence from Contract Changes in Southern California," American Economic Review, March 2004, 94 (1), 317-328.

Hunter, Graeme, Gregory K. Leonard, and Steven Olley, "Merger Retrospective Studies: A Review," Antitrust, 2008, 23, 34-41.

Kim, E. Han and Vijay Singal, "Mergers and Market Power: Evidence from the U.S. Airline Industry," American Economic Review, 1993, 83, 549-569. 
Moss, Diana, "Antitrust Analysis of Whirlpool's Proposed Acquisition of Maytag," Technical Report, American Antitrust Institute 2006.

Prager, Robin A. and Timothy H. Hannan, "Do Substantial Horizontal Mergers Generate Significant Price Effects? Evidence from the Banking Industry," Journal of Industrial Economics, December 1998, 46 (4), 433-52.

Sapienza, Paola, "The Effects of Banking Mergers on Loan Contracts," Journal of Finance, 2002, 1, 329-67.

Simpson, John and Christopher T. Taylor, "Do Gasoline Mergers Affect Consumer Prices? The Marathon Ashland Petroleum and Ultramar Diamond Shamrock Transaction," Journal of Law and Economics, 2008, 51 (1), 135-52.

Sweeting, Andrew, "The Effects of Mergers on Product Positioning: Evidence from the Music Radio Industry," RAND Journal of Economics, 2010, 41 (2), 372-97.

Taylor, Christopher T. and Daniel S. Hosken, "The Economic Effects of the Marathon-Ashland Joint Venture: The Importance of Industry Supply Shocks and Vertical Market Structure," Journal of Industrial Economics, 09 2007, 55 (3), 419451.

Weinberg, Matthew C., "The Price Effects of Horizontal Mergers," Journal of Competition Law and Economics, July 2008, 4 (2), 433-47.

Whinston, Michael D., Lectures on Antitrust Economics, Cambridge, MA: MIT Press, 2006.

Winston, Clifford, Scott Dennis, and Vikram Maheshri, "Long Run Effects of Mergers: The Case of US Western Railroads," forthcoming in Journal of Law and Economics. 
Figure 1: Average Log Price by Age

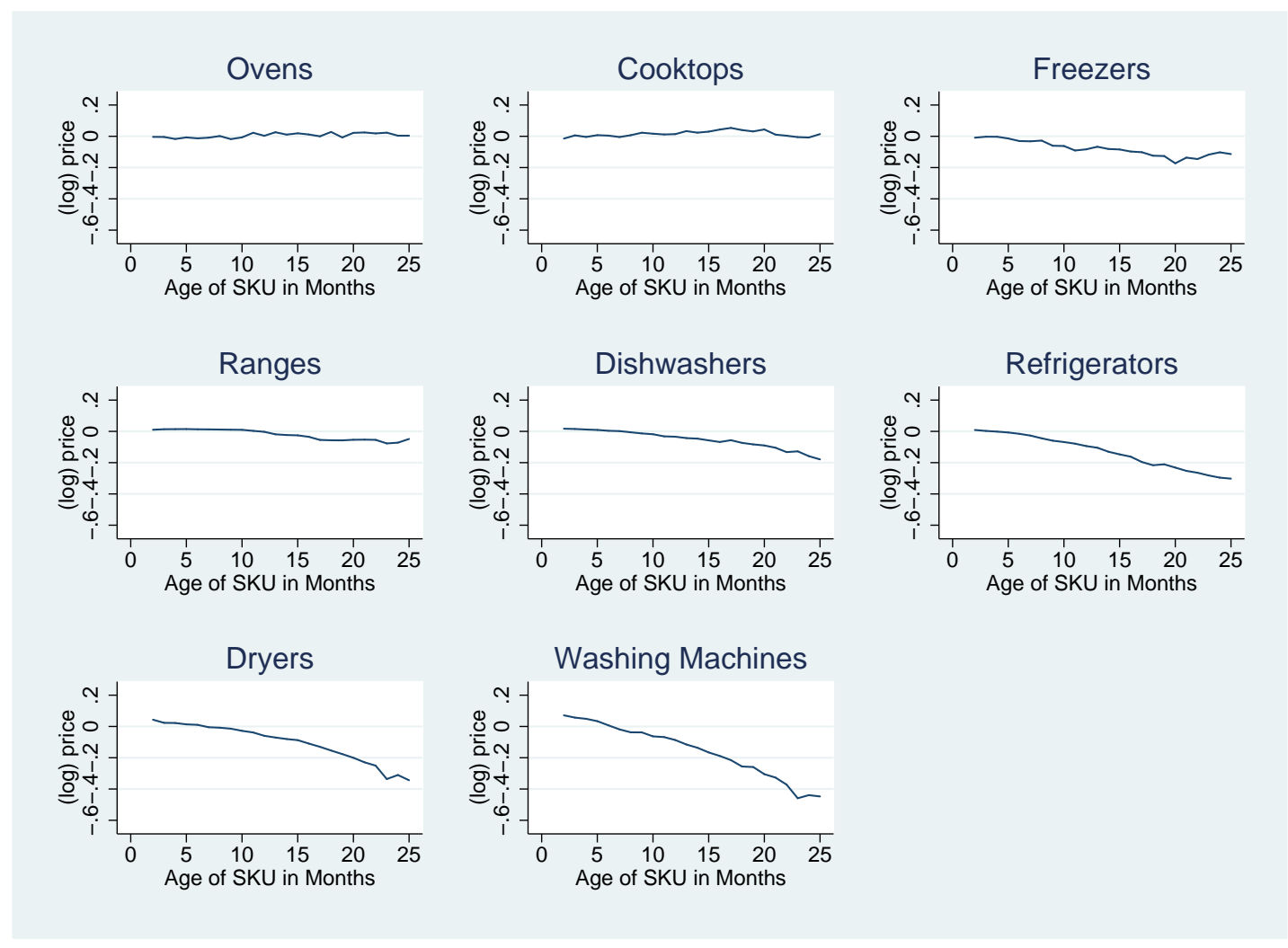

Notes: The figures plot coefficients on age dummies from a regression of log price on SKU fixed effects, age dummies, and time effects. Average log prices are measured relative to SKU's first month with positive sales. 
Figure 2: Average Log Volume by Age
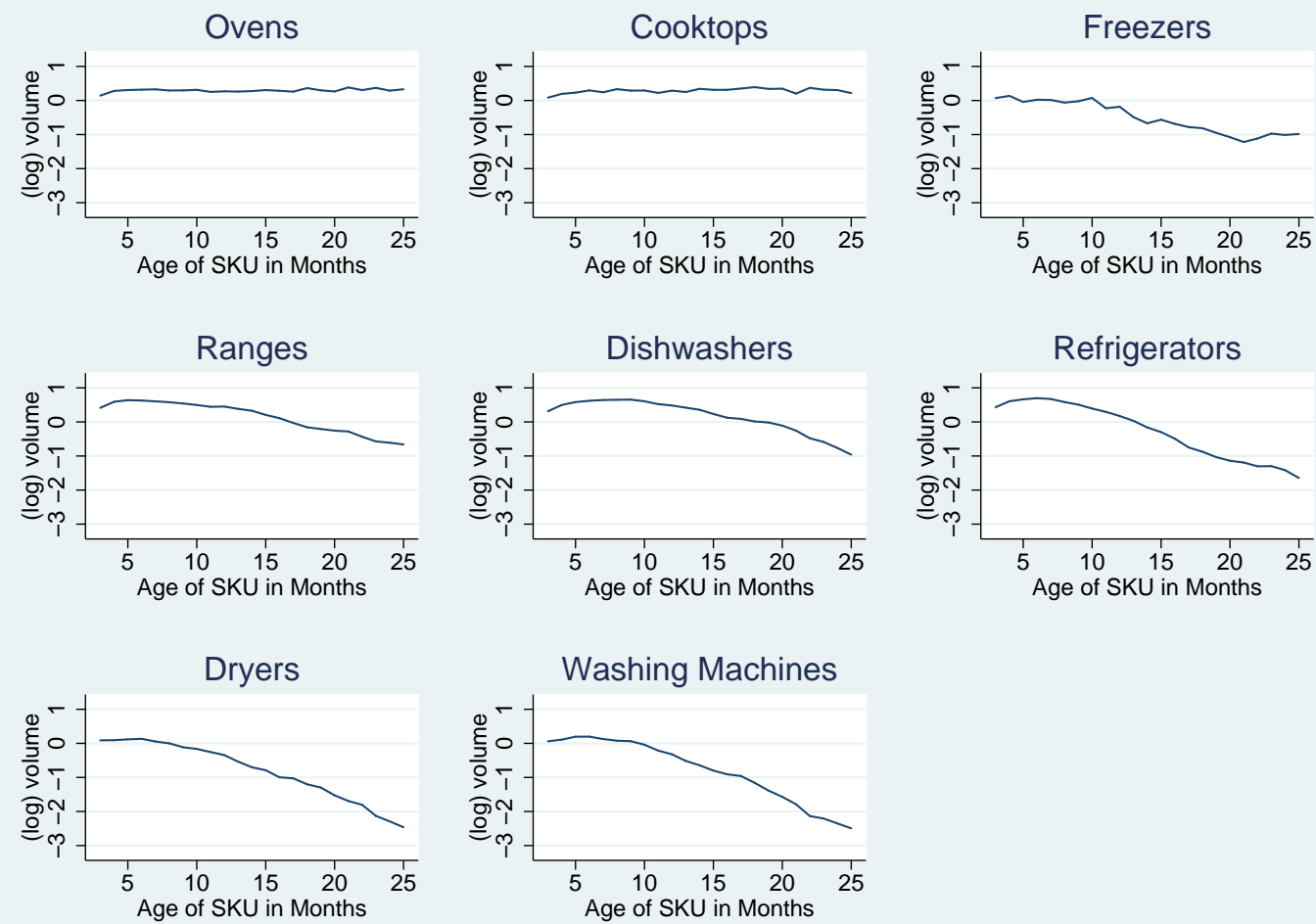

Notes: The figures plot coefficients on age dummies from a regression of log volume on SKU fixed effects, age dummies, and time effects. Average log prices are measured relative to SKU's first month with positive sales. 
Figure 3: Averages of Log Price: Freezer Comparison
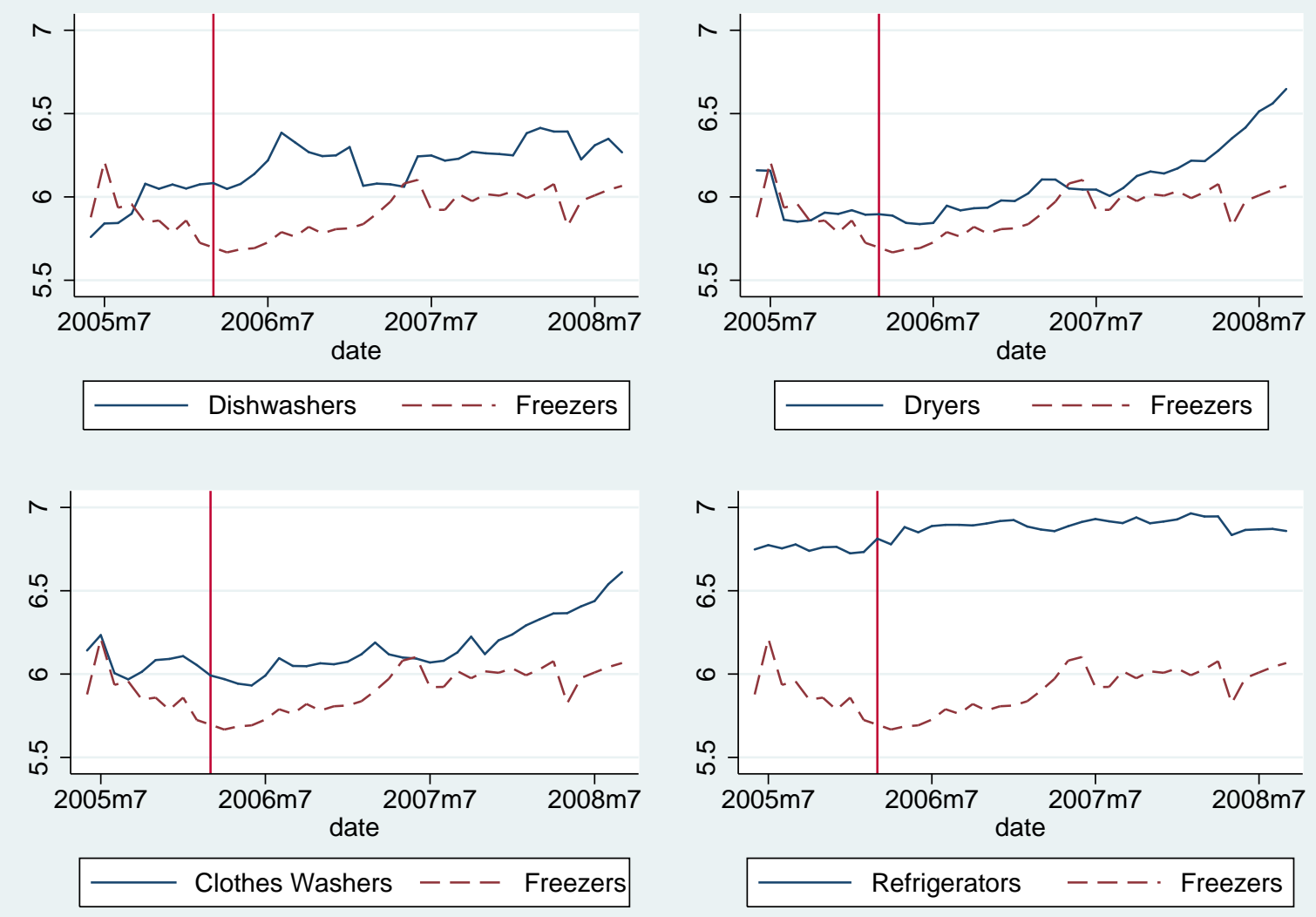

Notes: Solid line is average log price of either Maytag and Whirlpool dishwashers, clothes dryers, clothes washers, and refrigerators. Dashed line is average log price of freezers. The plot spans May of 2005-September of 2008. All products were born within the sample period. The vertical line corresponds to the merger's consummation date, April 2006. The merger was consummated on March 30, 2006. 
Figure 4: Averages of Log Price: Range Comparison
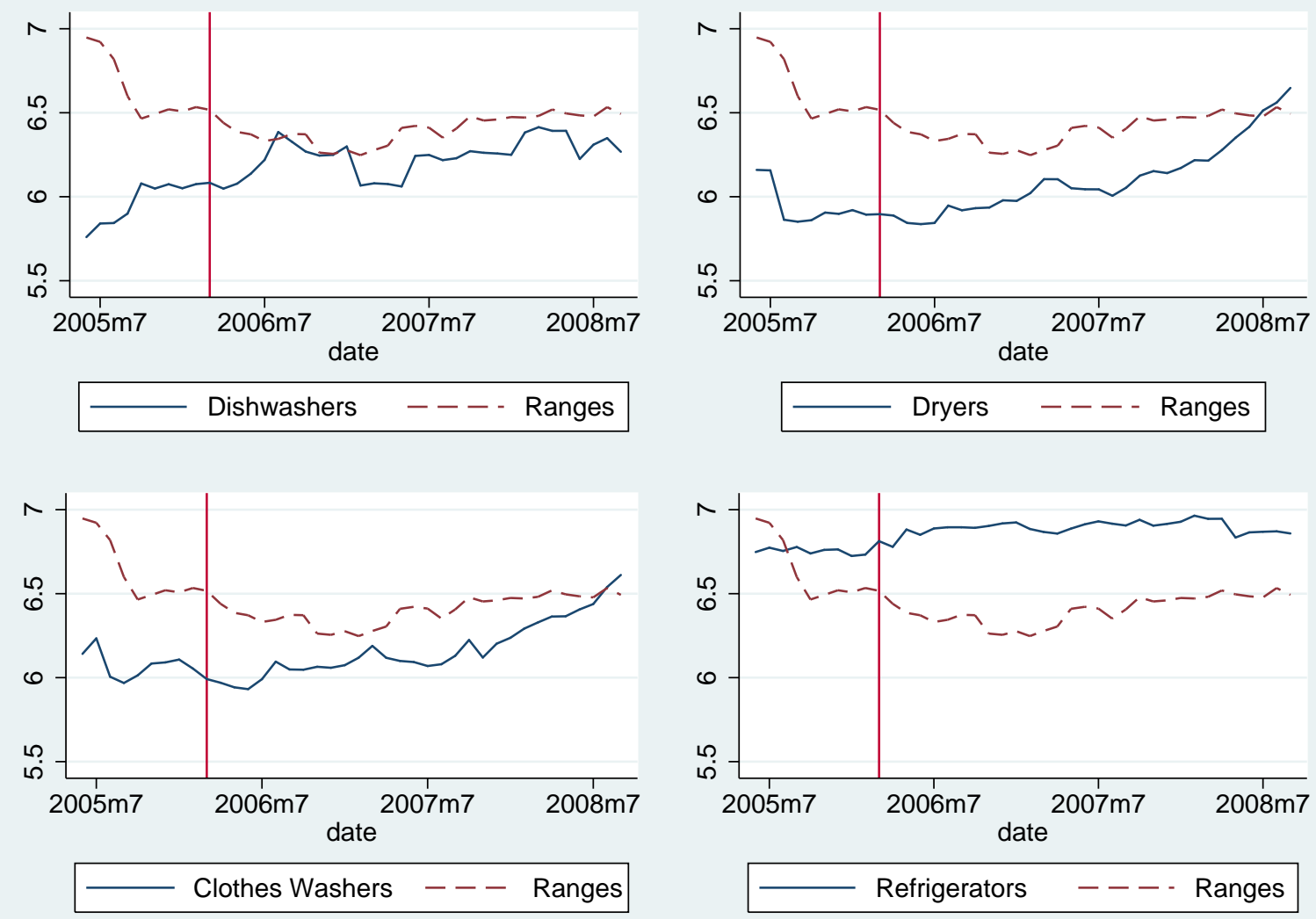

Notes: Solid line is average log price of either Maytag and Whirlpool dishwashers, clothes dryers, clothes washers, and refrigerators. Dashed line is average log price of ranges not produced by Maytag or Whirlpool. The plot spans May of 2005-September of 2008. All products were born within the sample period. The vertical line corresponds to the merger's consummation date, April 2006. The merger was consummated on March 30, 2006. 
Figure 5: Averages of Log Price Conditional on Product Characteristics and Age Dummies: Freezer Comparison
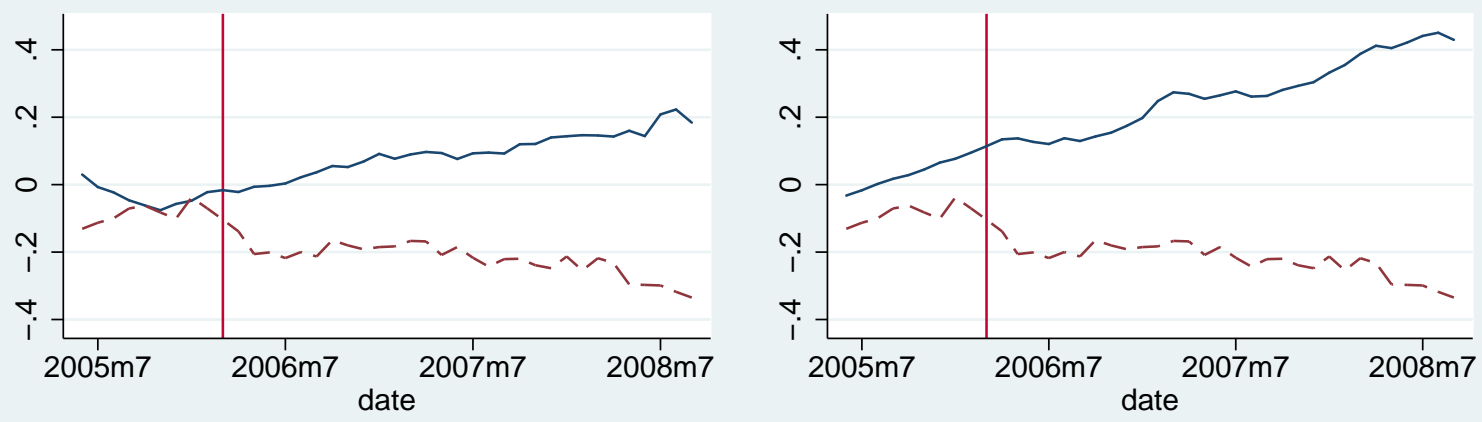

Dishwashers - - - Freezers

Dryers - - - Freezers
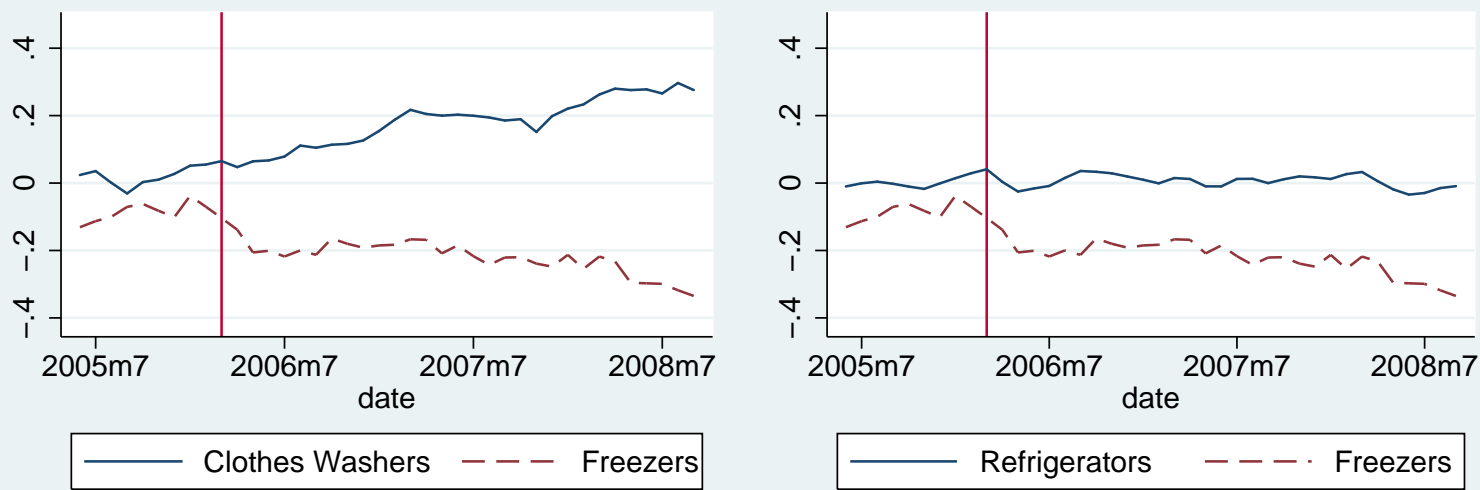

Notes: Solid line is age and characteristic adjusted average log price of either Maytag and Whirlpool dishwashers, clothes dryers, clothes washers, and refrigerators. Dashed line is age and characteristic adjusted average log price of freezers. The plot spans May of 2005-September of 2008. All products were born within the sample period. The vertical line corresponds to the merger's consummation date, April 2006. The merger was consummated on March 30, 2006. 
Figure 6: Averages of Log Price Conditional on Product Characteristics and Age Dummies: Range Comparison
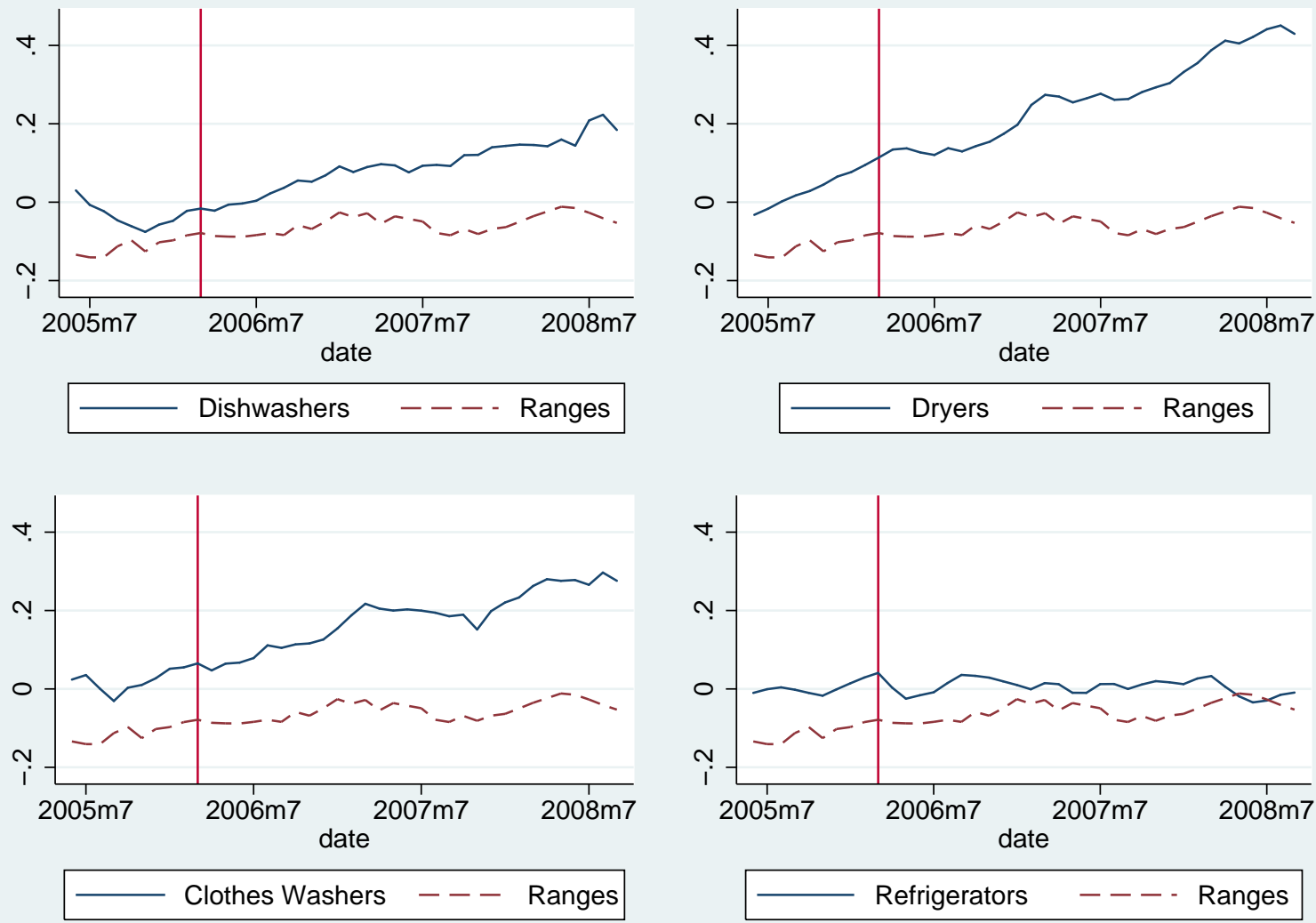

Notes: Solid line is age and characteristic adjusted average log price of either Maytag and Whirlpool dishwashers, clothes dryers, clothes washers, and refrigerators. Dashed line is age and characteristic adjusted average log price of ranges not produced by Maytag or Whirlpool. The plot spans May of 2005-September of 2008. All products were born within the sample period. The vertical line corresponds to the merger's consummation date, April 2006. The merger was consummated on March 30, 2006. 
Figure 7: SKU Counts
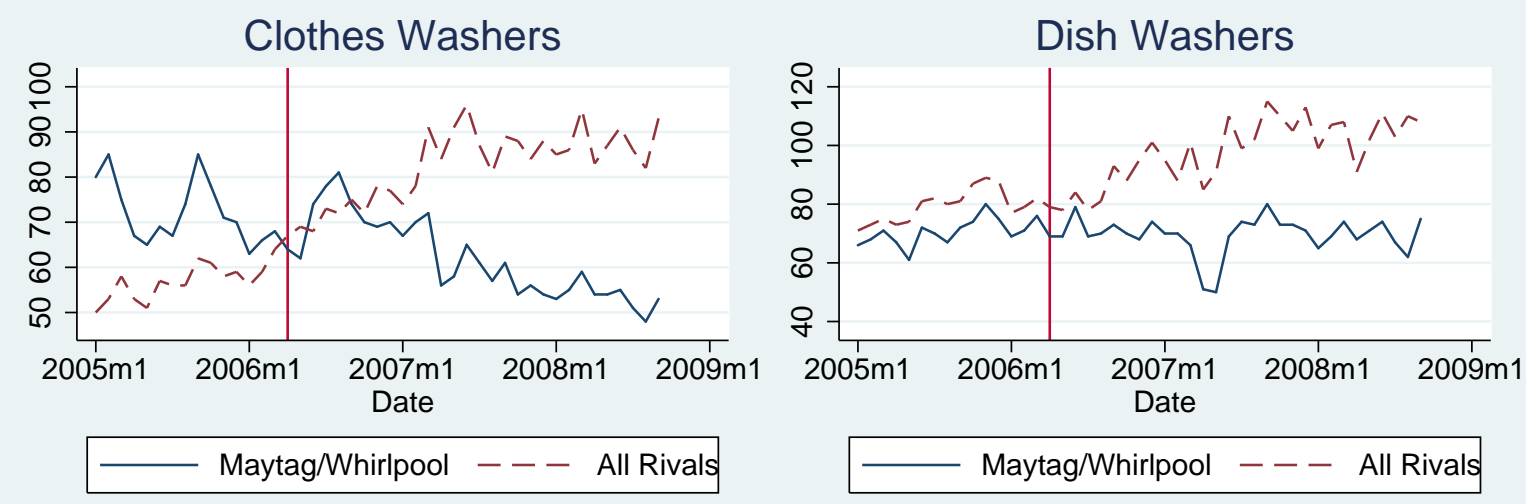

\section{Dryers}

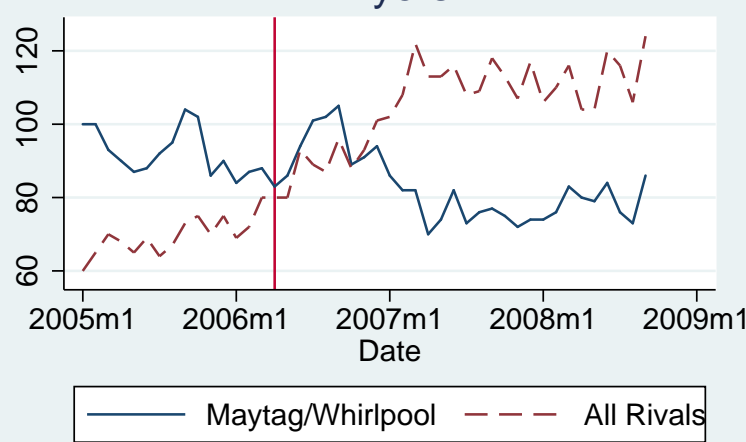

\section{Refrigerators}

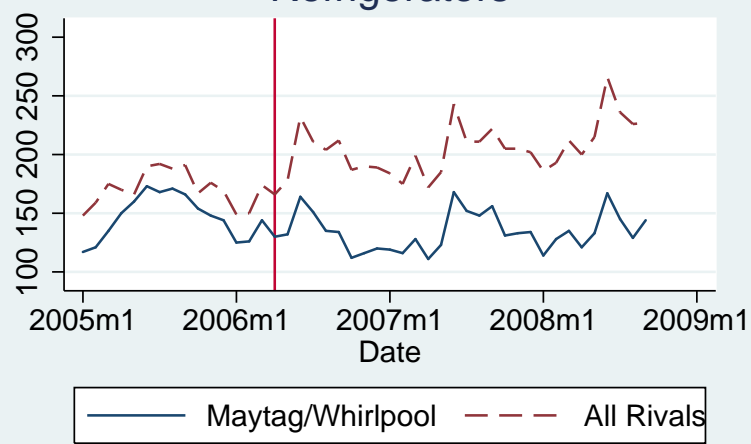

Notes: Solid lines are the count of Whirlpool/Maytag SKUs with at least 100 unit sales. Dashed line is the count for all other manufacturers. The plot spans January of 2005-September of 2008. All products were born within the sample period. The vertical line corresponds to the merger's consummation date, April 2006. The merger was consummated on March 30, 2006. 
Table 1: Pre-Merger Market Shares for Markets With Largest Change in Concentration Following Whirlpool-Maytag

\begin{tabular}{lc}
\multicolumn{2}{c}{ Dishwashers } \\
\hline Manufacturer & Revenue Share \\
Bosch & $6.2 \%$ \\
Electrolux & $25.1 \%$ \\
Fisher-Paykel & $2.4 \%$ \\
GE & $12.47 \%$ \\
LG & $1.6 \%$ \\
Maytag & $11.4 \%$ \\
Miele & $1.3 \%$ \\
Whirlpool & $38.6 \%$ \\
Other & $0.9 \%$ \\
Pre-Merger HHI & 2453 \\
Change in HHI & 880 \\
& \\
\multicolumn{2}{c}{ Refrigerators } \\
& \\
\hline Manufacturer & Revenue Share \\
Electrolux & $24.1 \%$ \\
GE & $10.9 \%$ \\
LG & $6.1 \%$ \\
Maytag & $9.2 \%$ \\
Samsung & $4.2 \%$ \\
Sub-Zero & $2.4 \%$ \\
Whirlpool & $41.8 \%$ \\
Other & $1.4 \%$ \\
Pre-Merger HHI & 2595 \\
Change in HHI & 770
\end{tabular}

\begin{tabular}{lc}
\multicolumn{2}{c}{ Clothes Dryers } \\
\hline Manufacturer & Revenue Share \\
Bosch & $1.9 \%$ \\
Electrolux & $8.9 \%$ \\
Fisher-Paykel & $1.8 \%$ \\
GE & $12.2 \%$ \\
LG & $9.6 \%$ \\
Maytag & $16.6 \%$ \\
Whirlpool & $48.8 \%$ \\
Other & $0.1 \%$ \\
Pre-Merger HHI & 2983 \\
Change in HHI & 1620
\end{tabular}

\begin{tabular}{lc}
\multicolumn{2}{c}{ Clothes Washers } \\
\hline Manufacturer & Revenue Share \\
Bosch & $2.4 \%$ \\
Electrolux & $13.8 \%$ \\
Fisher Paykel & $2.1 \%$ \\
GE & $10.5 \%$ \\
LG & $10.2 \%$ \\
Maytag & $16.8 \%$ \\
Whirlpool & $44.0 \%$ \\
Other & $0.3 \%$ \\
Pre-Merger HHI & 2632 \\
Change in HHI & 1478
\end{tabular}


Table 2: Pre-Merger Market Shares for Markets With Smaller or No Change in Concentration Following Whirlpool-Maytag

\begin{tabular}{|c|c|c|c|}
\hline \multicolumn{2}{|c|}{ Cooktop } & \multicolumn{2}{|c|}{ Freezer } \\
\hline Manufacturer & Revenue Share & Manufacturer & Revenue Share \\
\hline Bosch & $8.4 \%$ & Avanti Pro & $1.4 \%$ \\
\hline Dacor & $1.9 \%$ & Electrolux & $81.3 \%$ \\
\hline Electrolux & $19.1 \%$ & Haier & $12.8 \%$ \\
\hline Fisher-Paykel & $1.4 \%$ & Other & $2.0 \%$ \\
\hline GE & $20.8 \%$ & Sub-Zero & $1.5 \%$ \\
\hline Maytag & $9.5 \%$ & Wood & $1.0 \%$ \\
\hline Miele & $1.1 \%$ & Pre-Merger HHI & 6789 \\
\hline Other & $0.00 \%$ & Change in HHI & 0 \\
\hline Sub-Zero & $8.2 \%$ & & \\
\hline Viking & $7.6 \%$ & & \\
\hline Whirlpool & $22.0 \%$ & & \\
\hline Pre-Merger HHI & 1571 & & \\
\hline Change in HHI & 416 & & \\
\hline \multicolumn{2}{|c|}{ Oven } & \multicolumn{2}{|c|}{ Range } \\
\hline Manufacturer & Revenue Share & Manufacturer & Revenue Share \\
\hline Bosch & $10.1 \%$ & Bosch & $1.2 \%$ \\
\hline Dacor & $1.9 \%$ & Electrolux & $37.6 \%$ \\
\hline Electrolux & $10.5 \%$ & GE & $25.3 \%$ \\
\hline Fisher-Paykel & $1.6 \%$ & Maytag & $5.2 \%$ \\
\hline GE & $23.1 \%$ & Other & $1.0 \%$ \\
\hline Maytag & $6.3 \%$ & Premier & $1.7 \%$ \\
\hline Miele & $2.3 \%$ & Sub-Zero & $1.8 \%$ \\
\hline Other & $0.00 \%$ & Viking & $1.7 \%$ \\
\hline Sub-Zero & $7.9 \%$ & Whirlpool & $24.7 \%$ \\
\hline Viking & $3.8 \%$ & Pre-Merger HHI & 2703 \\
\hline Whirlpool & $32.5 \%$ & Change in HHI & 256 \\
\hline Pre-Merger HHI & 1929 & & \\
\hline Change in HHI & 412 & & \\
\hline
\end{tabular}


Table 3: Price Effects of Dryers Relative to Other Appliances

\begin{tabular}{lcccc}
\hline \hline & \multicolumn{4}{c}{ Comparison Category } \\
\cline { 2 - 5 } & Cooktops & Freezers & Ovens & Ranges \\
\hline \multirow{2}{*}{ Post*Old*Whirlpool } & -0.0172 & 0.0291 & -0.0654 & -0.0602 \\
& $(0.0198)$ & $(0.0347)$ & $(0.0218)$ & $(0.0176)$ \\
Post*Old*Maytag & 0.0437 & 0.0903 & -0.0102 & 0.000473 \\
& $(0.0132)$ & $(0.0310)$ & $(0.0153)$ & $(0.00671)$ \\
& & & & \\
Post*New*Whirlpool & 0.133 & 0.140 & 0.171 & 0.144 \\
& $(0.0653)$ & $(0.0479)$ & $(0.0471)$ & $(0.0542)$ \\
Post*New*Maytag & 0.00486 & 0.0113 & 0.0574 & 0.0318 \\
& $(0.0864)$ & $(0.0622)$ & $(0.0623)$ & $(0.0757)$ \\
& & & & \\
\hline Observations & 2657 & 2206 & 2563 & 4429 \\
Number of SKU & 250 & 225 & 240 & 403 \\
\hline
\end{tabular}

Notes: Standard errors in parentheses allow for arbitrary serial correlation and heteroskedasticity within SKU. Product characteristics included in all specifications. Authors' own calculations on monthly NPD data from April 2005 through September 2008.

Table 4: Price Effects of Dishwashers Relative to Other Appliances

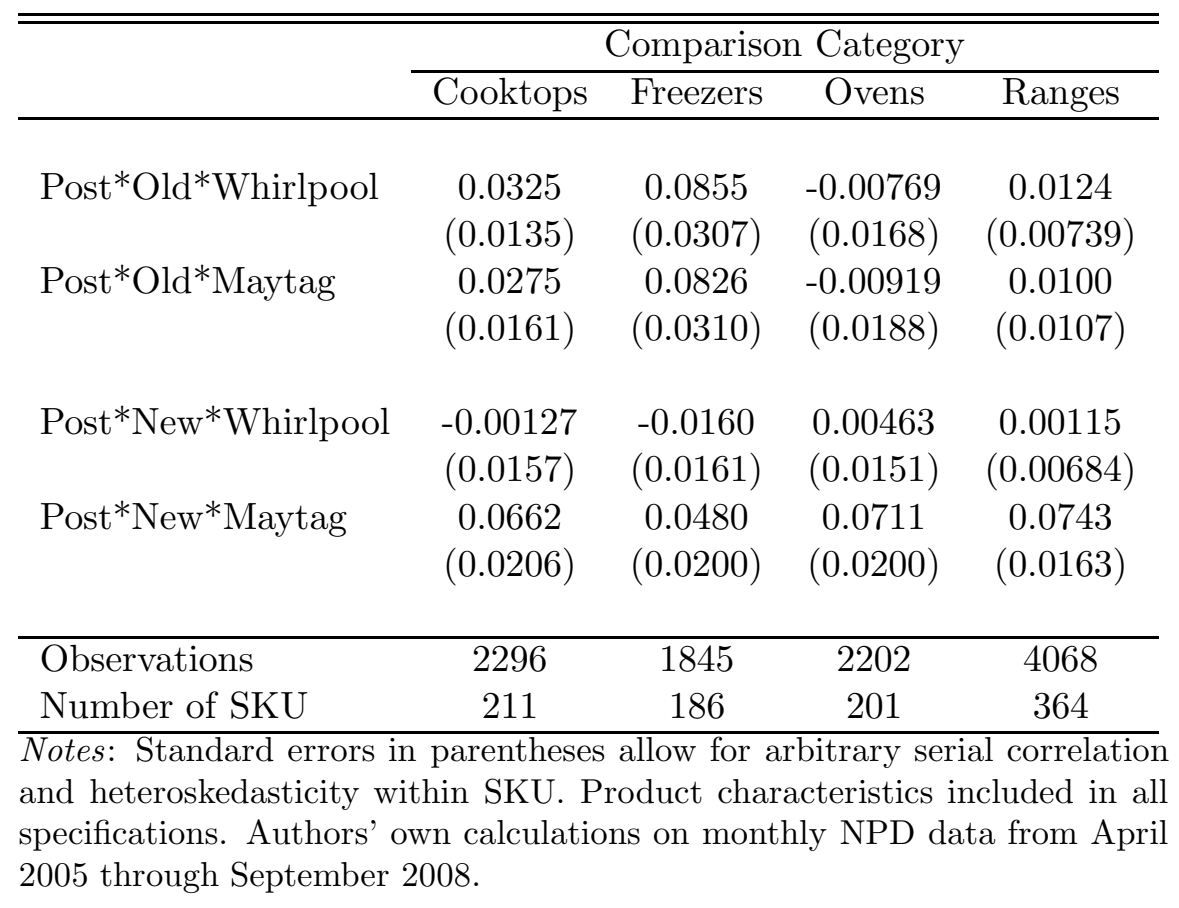


Table 5: Price Effects of Refrigerators Relative to Other Appliances

\begin{tabular}{lcccc}
\hline \hline & \multicolumn{4}{c}{ Comparison Category } \\
\cline { 2 - 5 } & Cooktops & Freezers & Ovens & Ranges \\
\hline \multirow{2}{*}{ Post*Old*Whirlpool } & -0.0213 & 0.0455 & -0.0465 & -0.0221 \\
& $(0.0227)$ & $(0.0341)$ & $(0.0240)$ & $(0.0202)$ \\
Post*Old*Maytag & -0.0266 & 0.0370 & -0.0506 & -0.0254 \\
& $(0.0267)$ & $(0.0363)$ & $(0.0286)$ & $(0.0251)$ \\
& & & & \\
Post*New*Whirlpool & 0.0388 & 0.0194 & 0.0389 & 0.0210 \\
Post*New*Maytag & $(0.0159)$ & $(0.0164)$ & $(0.0145)$ & $(0.00951)$ \\
& 0.00602 & -0.00641 & 0.0157 & 0.00960 \\
& $(0.0212)$ & $(0.0229)$ & $(0.0200)$ & $(0.0164)$ \\
\hline Observations & & & & \\
Number of sku1 & 3534 & 3083 & 3440 & 5306 \\
\hline Notes: Stam & 359 & 334 & 349 & 512 \\
\hline
\end{tabular}

Notes: Standard errors in parentheses allow for arbitrary serial correlation and heteroskedasticity within SKU. Product characteristics included in all specifications. Authors' own calculations on monthly NPD data from April 2005 through September 2008.

Table 6: Price Effects of Washers Relative to Other Appliances

\begin{tabular}{lcccc}
\hline \hline & \multicolumn{4}{c}{ Comparison Category } \\
\cline { 2 - 5 } & Cooktops & Freezers & Ovens & Ranges \\
\hline \multirow{3}{*}{ Post*Old*Whirlpool } & -0.00856 & 0.0341 & -0.0556 & -0.0431 \\
& $(0.0256)$ & $(0.0373)$ & $(0.0273)$ & $(0.0231)$ \\
Post*Old*Maytag & 0.0383 & 0.0848 & -0.0117 & 0.00310 \\
& $(0.0177)$ & $(0.0318)$ & $(0.0195)$ & $(0.0127)$ \\
& & & & \\
Post*New*Whirlpool & -0.0175 & -0.0409 & -0.0150 & -0.0202 \\
& $(0.0171)$ & $(0.0175)$ & $(0.0176)$ & $(0.0106)$ \\
Post*New*Maytag & 0.0157 & -0.00743 & 0.0223 & 0.0171 \\
& $(0.0179)$ & $(0.0179)$ & $(0.0180)$ & $(0.0111)$ \\
& \multicolumn{5}{c}{1813} \\
\hline Observations & 2264 & 2170 & 4036 \\
Number of SKU & 218 & 193 & 208 & 371 \\
\hline Notes: Standard errors in parentheses allow for arbitrary serial correlation \\
and heteroskedasticity within SKU. Product characteristics included in all \\
specifications. Authors' own calculations on monthly NPD data from April \\
2005 through September 2008.
\end{tabular}


Table 7: Price Effects of Merging Party Appliances Relative to Rivals

\begin{tabular}{lcccc}
\hline \hline & \multicolumn{4}{c}{ Appliance Type } \\
\cline { 2 - 5 } & Dishwashers & Refrigerators & Dryers & Washers \\
\hline \multirow{2}{*}{ Post*Old*Whirlpool } & 0.024 & -0.044 & -0.055 & -0.040 \\
& $(0.008)$ & $(0.021)$ & $(0.018)$ & $(0.027)$ \\
Post*Old*Maytag & 0.030 & -0.045 & 0.008 & 0.006 \\
& $(0.011)$ & $(0.025)$ & $(0.008)$ & $(0.017)$ \\
Post*New*Whirlpool & 0.014 & 0.008 & 0.073 & -0.047 \\
& $(0.007)$ & $(0.009)$ & $(0.030)$ & $(0.013)$ \\
Post*New*Maytag & 0.082 & -0.026 & -0.002 & -0.014 \\
& $(0.015)$ & $(0.017)$ & $(0.040)$ & $(0.014)$ \\
& & & & \\
\hline Observations & 2895 & 5902 & 3088 & 2456 \\
Number of SKU & 257 & 605 & 284 & 232 \\
\hline
\end{tabular}

Notes: Standard errors in parentheses allow for arbitrary serial correlation and heteroskedasticity within SKU. Product characteristics included in all specifications. Authors' own calculations on monthly NPD data from April 2005 through September 2008. 
Table 8: Change in Whirlpool/Maytag's Market Share and Product Offerings Following the Merger

\begin{tabular}{lcccc}
\hline Product & \multicolumn{2}{c}{$\begin{array}{c}\text { Change in } \\
\text { Share }\end{array}$} & $\begin{array}{c}\text { Absolute } \\
\text { Change in } \\
\text { Products } \\
\text { Offered }^{b}\end{array}$ & $\begin{array}{c}\text { Relative } \\
\text { Change in } \\
\text { Products } \\
\text { Offered }^{c}\end{array}$ \\
\hline \multirow{5}{*}{ Dish Washer } & $\begin{array}{c}\text { Revenue } \\
\text { Share }\end{array}$ & $\begin{array}{c}\text { Volume } \\
\text { Share }\end{array}$ & & \\
Clothes Dryer & -0.046 & -0.043 & -1.067 & -0.219 \\
Refrigerator & $-0.010)$ & $(0.011)$ & $(1.862)$ & $(0.044)$ \\
& $(0.009)$ & -0.068 & -9.767 & -0.527 \\
Clothes Washer & -0.086 & -0.110 & -12.500 & -0.266 \\
& $(0.011)$ & $(0.013)$ & $(5.392)$ & $(0.050)$ \\
& -0.073 & -0.053 & -10.367 & -0.527 \\
& $(0.008)$ & $(0.007)$ & $(2.613)$ & $(0.050)$ \\
\hline Observations & & & & \\
\hline
\end{tabular}

Notes: ${ }^{a}$ Regression of market share on merger indicator. ${ }^{b}$ Regression of the number of SKU's with more than 100 unit sales in a month on Merger indicator. ${ }^{c}$ Regression of the log of the number of SKU's with more than 100 unit sales in a month on Merger indicator, Whirlpool/Maytag indicator, and their interaction. Standard errors in parentheses. Authors' own calculations on monthly NPD data from April 2005 through September 2008. 


\section{A Data Appendix}

This section describes the product characteristics available in the NPD data and used as controls in specification 5, For dishwashers, we have dummy variables indicating if the product is stainless steel, has a stainless steel look, is black, has some other color, is not digital, is energy star certified, has a stainless steel interior, has 1-4 cycles, has 5 cycles, has 6 cycles, has sound control, and is portable.

For refrigerators, we include dummy variables indicating if the product is stainless steel, has a stainless steel look, is black, is some other color, has an ice and water dispenser in the door, has crisper and meat drawers, is energy star certified, has an ice maker, has wire shelves, and has a water filtration system. We also include 8 depth dummies, 7 height dummies, 14 capacity dummies, and 5 width dummies.

For clothes washers, we include dummy variables indicating if the product is stainless steel, black, some other color, is pre-stacked or stackable, has a soil sensor, has a load sensor, has between 700 and 1000 RPMs, and 8 dummies indicating number of cycles and 3 dummies indicating capacity. We do not include an indicator for front-loading washers because this indicator was collinear with the other controls we used. Recall, we focus on washers produced by Maytag and Whirlpool, which were not large manufacturers of front loading washers.

For clothes dryers, we include dummy variables indicating if the product is stainless steel, black, some other color, has a delicate cycle, has a drop down door, has a dryer rack included, is more than 27 inches in width, is gas powered, and 3 capacity dummies, 7 number of program dummies, and 7 temperature dummies.

For freezers, we include variables indicating if the product is stainless steel, has a defrost drain, has an ice maker, has a light, has a lock, has baskets, is a chest, and 9 size dummies. We also include indicators of whether the freezer has 3, 4, 5, or 8 shelves.

For ovens, we include dummy variables indicating if the product is stainless steel, has 
no cleaning option, is electric, has a convection fan, is a double oven, has a microwave, 4 capacity dummies, and 2 width dummies.

For cooktops, we include dummy variables indicating if the product is stainless steel, is black, has an electronic timer, has an electric coil, has a mechanical timer, and 2 width dummies.

For ranges, we include dummy variables indicating if the product is stainless steel, has a stainless steel look, is black, has some other color, includes a convection oven, includes a microwave, is double conventional, has electronic controls and timer, has a mechanical timer, has an electric coil, has sealed burners, has electronic ignition, is a slide in range, and 4 capacity dummies and 4 width dummies. 


\section{B Additional Tables}


Table 1: Comparison of Estimated Price Effects Relative to Cooktops Using SKU Fixed Effects and Product Characteristics

\begin{tabular}{|c|c|c|c|c|c|c|c|c|}
\hline \multirow[b]{2}{*}{ Post*Whirlpool } & \multicolumn{2}{|c|}{ Dishwashers } & \multicolumn{2}{|c|}{ Dryers } & \multicolumn{2}{|c|}{ Refrigerators } & \multicolumn{2}{|c|}{ Washers } \\
\hline & 0.0432 & 0.0415 & $-0.0 \overline{292}$ & -0.0298 & -0.0196 & -0.0209 & -0.0277 & -0.0282 \\
\hline \multirow{3}{*}{ Post*Maytag } & $(0.0228)$ & $(0.0234)$ & $(0.0308)$ & $(0.0314)$ & $(0.0280)$ & $(0.0283)$ & $(0.0365)$ & $(0.0365)$ \\
\hline & 0.0327 & 0.0324 & 0.0332 & 0.0327 & -0.0310 & -0.0316 & 0.0167 & 0.0176 \\
\hline & $(0.0211)$ & $(0.0216)$ & $(0.0199)$ & $(0.0206)$ & $(0.0432)$ & $(0.0434)$ & $(0.0251)$ & $(0.0257)$ \\
\hline SKU Fixed Effects & Yes & $\mathrm{No}$ & Yes & $\mathrm{No}$ & Yes & $\mathrm{No}$ & Yes & $\mathrm{No}$ \\
\hline Product Characteristics & No & Yes & No & Yes & No & Yes & No & Yes \\
\hline Observations & 1392 & 1392 & 1449 & 1449 & 2025 & 2025 & 1275 & 1275 \\
\hline Number of SKUs & 153 & 153 & 179 & 179 & 231 & 231 & 155 & 155 \\
\hline
\end{tabular}

Notes: Estimated on the set of products that were sold before and after the merger. Standard errors in parentheses allow for arbitrary heteroskedasticity and serial correlation within an SKU. Authors' own calculations on monthly NPD data from April 2005 through September 2008 . 
Table 2: Comparison of Estimated Price Effects Relative to Freezers Using SKU Fixed Effects and Product Characteristics

\begin{tabular}{|c|c|c|c|c|c|c|c|c|}
\hline \multirow[b]{2}{*}{ Post*Whirlpool } & \multicolumn{2}{|c|}{ Dishwashers } & \multicolumn{2}{|c|}{ Dryers } & \multicolumn{2}{|c|}{ Refrigerators } & \multicolumn{2}{|c|}{ Washers } \\
\hline & 0.120 & 0.105 & $0.0 \overline{57}$ & 0.0433 & $\overline{0.0866}$ & 0.0663 & 0.0575 & 0.0466 \\
\hline & $(0.0360)$ & $(0.0331)$ & $(0.0374)$ & $(0.0345)$ & $(0.0391)$ & $(0.0348)$ & $(0.0420)$ & $(0.0382)$ \\
\hline \multirow[t]{2}{*}{ Post*Maytag } & 0.109 & 0.0979 & 0.121 & 0.110 & 0.0698 & 0.0511 & 0.106 & 0.0975 \\
\hline & $(0.0353)$ & $(0.0327)$ & $(0.0343)$ & $(0.0314)$ & $(0.0422)$ & $(0.0372)$ & $(0.0366)$ & $(0.0330)$ \\
\hline SKU Fixed Effects & Yes & No & Yes & No & Yes & No & Yes & No \\
\hline Product Characteristics & No & Yes & No & Yes & No & Yes & No & Yes \\
\hline Observations & 1088 & 1088 & 1145 & 1145 & 1721 & 1721 & 971 & 971 \\
\hline SKUs & 121 & 121 & 147 & 147 & 199 & 199 & 123 & 123 \\
\hline
\end{tabular}

Notes: Estimated on the set of products that were sold before and after the merger. Standard errors in parentheses allow for arbitrary heteroskedasticity and serial correlation within an SKU. Authors' own calculations on monthly NPD data from April 2005 through September 2008. 
Table 3: Comparison of Estimated Price Effects Relative to Ovens Using SKU Fixed Effects and Product Characteristics

\begin{tabular}{|c|c|c|c|c|c|c|c|c|}
\hline \multirow[b]{2}{*}{ Post*Whirlpool } & \multicolumn{2}{|c|}{ Dishwashers } & \multicolumn{2}{|c|}{ Dryers } & \multicolumn{2}{|c|}{ Refrigerators } & \multicolumn{2}{|c|}{ Washers } \\
\hline & $\begin{array}{c}0.0268 \\
(0.0320)\end{array}$ & $\begin{array}{c}0.0196 \\
(0.0323)\end{array}$ & $\begin{array}{c}-0 . \overline{000} \\
(0.0452)\end{array}$ & $\begin{array}{c}-0.102 \\
(0.0446)\end{array}$ & $\begin{array}{l}-0.0392 \\
(0.0324)\end{array}$ & $\begin{array}{c}-0.0433 \\
(0.0307)\end{array}$ & $\begin{array}{c}-0.0656 \\
(0.0444)\end{array}$ & $\begin{array}{c}-0.0667 \\
(0.0424)\end{array}$ \\
\hline Post*i & $\begin{array}{c}0.0196 \\
(0.0311)\end{array}$ & $\begin{array}{c}0.0165 \\
(0.0314)\end{array}$ & $\begin{array}{c}-0.0388 \\
(0.0376)\end{array}$ & $\begin{array}{l}-0.0413 \\
(0.0367)\end{array}$ & $\begin{array}{l}-0.0491 \\
(0.0491)\end{array}$ & $\begin{array}{c}-0.0516 \\
(0.0477)\end{array}$ & $\begin{array}{l}-0.0228 \\
(0.0358)\end{array}$ & $\begin{array}{l}-0.0205 \\
(0.0348)\end{array}$ \\
\hline SKU Fixed Eff & Yes & No & Yes & No & Yes & No & Yes & No \\
\hline Product Characteristics & No & Yes & No & Yes & No & Yes & No & Yes \\
\hline Observations & 1088 & 1088 & 1145 & 1145 & 1721 & 1721 & 971 & 971 \\
\hline Number of SKUs & 120 & 120 & 146 & 146 & 198 & 198 & 122 & 122 \\
\hline
\end{tabular}

Notes: Estimated on the set of products that were sold before and after the merger. Standard errors in parentheses allow for arbitrary heteroskedasticity and serial correlation within an SKU. Authors' own calculations on monthly NPD data from April 2005 through September 2008 . 
Table 4: Comparison of Estimated Price Effects Relative to Ranges Using SKU Fixed Effects and Product Characteristics

\begin{tabular}{|c|c|c|c|c|c|c|c|c|}
\hline \multirow[b]{2}{*}{ Post*Whirlpool } & \multicolumn{2}{|c|}{ Dishwashers } & \multicolumn{2}{|c|}{ Dryers } & \multicolumn{2}{|c|}{ Refrigerators } & \multicolumn{2}{|c|}{ Washers } \\
\hline & 0.0299 & 0.0284 & $-0.0 \overline{339}$ & -0.0349 & -0.0143 & -0.0160 & -0.0341 & -0.0351 \\
\hline & $(0.0170)$ & $(0.0173)$ & $(0.0298)$ & $(0.0301)$ & $(0.0271)$ & $(0.0271)$ & $(0.0347)$ & $(0.0346)$ \\
\hline \multirow[t]{2}{*}{ Post*Maytag } & 0.0168 & 0.0164 & 0.0285 & 0.0275 & -0.0257 & -0.0266 & 0.0104 & 0.0105 \\
\hline & $(0.0163)$ & $(0.0165)$ & $(0.0168)$ & $(0.0171)$ & $(0.0416)$ & $(0.0416)$ & $(0.0211)$ & $(0.0213)$ \\
\hline SKU Fixed Effects & Yes & No & Yes & No & Yes & No & Yes & No \\
\hline Product Characteristics & No & Yes & No & Yes & No & Yes & No & Yes \\
\hline Observations & 2072 & 2072 & 2129 & 2129 & 2705 & 2705 & 1955 & 1955 \\
\hline Number of SKUs & 213 & 213 & 239 & 239 & 291 & 291 & 215 & 215 \\
\hline
\end{tabular}

Notes: Estimated on the set of products that were sold before and after the merger. Standard errors in parentheses allow for arbitrary heteroskedasticity and serial correlation within an SKU. Authors' own calculations on monthly NPD data from April 2005 through September 2008 . 